\title{
OCORRÊNCIA E ADAPTABILIDADE DE LINHAGENS DE Botrytis squamosa RESISTENTES A FUNGICIDAS DO GRUPO DOS BENZIMIDAZÓIS E DICARBOXIMIDAS
}

\author{
RAQUEL GHINI
}

Engenheiro Agrônomo

Orientador: Prof. Dr. HIROSHI KIMATI

Tese apresentada à Escola Superior de Agricultura "Luiz de Queiroz", da Universidade de São Paulo, para obtenção do título de Doutor em Agronomia. Área de Concentração: Fitopatologia.

PIRACICABA

Estado de São Paulo - Brasil

Dezembro - 1987 
OCORRENCIA E ADAPTABILIDADE DE LINHAGENS DE BOTRYTIS SQUAMOSA RESISTENTES A FUNGICIDAS DO GRUPO DOS BENZIMIDAZOIS E DICARBOXIMIDAS

RAQUEL GHINI

Aprovada em: 02.02 .1988

Comissão julgadora:

- Prof. Dr. Hiroshi Kimati

$\because A L Q / U S P$

- Prof. Dr. Keigo Minami

ESALO/USP

- Prof. Dr. Tasso Leo Krulgner ESALQ/USP

- Prof. Dr. José otávio Machado Menten ESALQ/USP

- Prof. Dr. Chukichi Kurozawa UIIESP/Botucatu

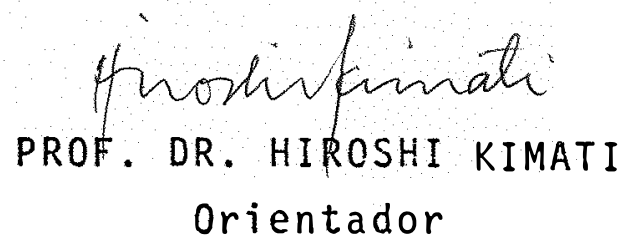


A

meus pais e

minhà irmã,

dedico. 


\section{AGRADECIMENTOS}

A autora expressa seus agradecimentos a todos que contribuiram para a realização desde trabalho, em espe cial:

Ao Professor Dr. Hiroshi Kimati, pela preciosa orientação, interesse, amizade, confiança e pelo exemplo de dedicação ao trabalho.

Ao Dr. Wagner Bettiol, pela amizade, inestimáa vel apoio, estímulo e auxỉio na realização deste trabalho.

Aos professores do Departamento de Fitopatolo gia da Escola Superior de Agricultura "Luiz de Queiroz", pelos ensinamentos e amizade.

Aos colegas de curso: Dra. Beatriz M. J. Mendes, M. S. Celso Garcia Auer, M. S. Gisèie M. Fantin, Dra. Margarete Camargo e Dra. Maria Aparecida Pessóa da Cruz Centurion, pela amizade e auxilio durante a realização deste trabalho.

Aos pesquisadores Dra. Rosa Maria Valdebenito Sanhueza, Dr. Walter Becker e M. S. Antonio Paulo Ronchi,pe 10 envio de folhas de cebola com sintoma de queima das pontas.

Ao Prof. Dr. Cyro Paulino da Costa, pelo gentil fornecimento de sementes de cebola. 
$\ddot{A}$ M.S. Margarida M.H.Zaroni, pelo auxilio na anälise estatistica dos dados.

À biblioteconomista Maria Amélia de T. Leme, pela ajuda na preparação da literatura citada.

Ao Prof. Dr. Tasso Leo Krügner, pela elaboração do "Summary".

À FAPESP, pela concessão da bolsa de estudos.

À EMBRAPA/CNPDA, pelo auxílio financeiro concedido para a realização deste trabalho de pesquisa. 
$v i$ i

SUMARIO

Pägina

LISTA DE TABELAS..................... ix

RESUMO $\ldots \ldots \ldots \ldots \ldots \ldots \ldots \ldots \ldots \ldots \ldots \ldots \ldots \ldots \ldots \ldots \ldots \ldots \ldots \ldots \ldots$

SUMMARY ............................. xiv

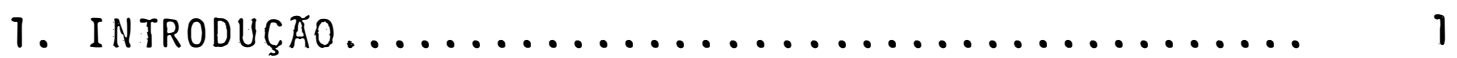

2. REVISATO DE LITERATURA................. 4

2.1. Resistência de fungos a fungicidas....... 4

2.2. Benzimidazöis.................... 7

2.2.1. Modo de ação e seletividade....... 9

2.2.2. Resistência................. 11

2.3. Dicarboximidas................... 19

2.3.1. Modo de ação.............. 20

2.3.2. Resistēncia................ 22

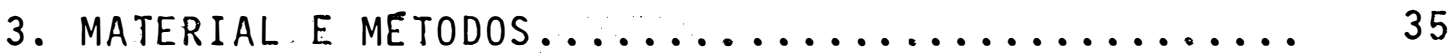

3.1. Is 01 amento.............................. 35

3.2. Preservação do fungo................. 37

3.3. Produção de conĩdios...................... 37

3.4. Frequência e grau de resistência......... 38

3.5. Ob tenção da 1 inhagem resistente a benomy 1.. 39

3.6. Ob tenção da 1 inhagem resistente a iprodione... 40

3.7. Obtenção da linhagem duplo-resistente..... 41

3.8. Sensibilidade colateral.............. 44

3.9. Adaptabilidade .................. 46

3.9.1. Crescimento micelial.......... 46 
3.9.2. Es porul ação............... 47

3.9.3. Patogenicidade............... 48

3.9.4. Competição in vitro.............. 49

3.9.5. Competição in vivo............. 51

3.9.6. Estabilidade da resistência a benomy 154

3.9.7. Estabilidade da resistência a benomy 1 e iprodione.................. 55

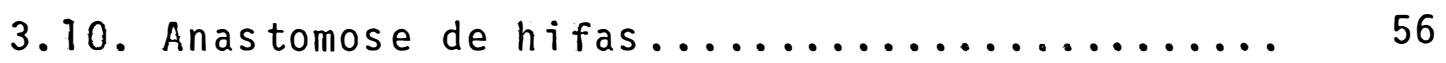

3.11. Coloração de nūcteos de conĩdios.......... 57

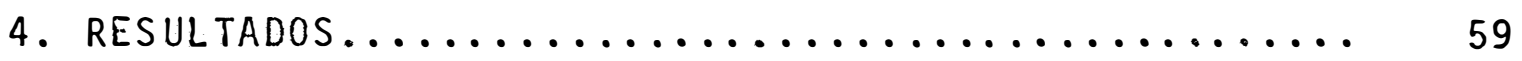

4.1. Frequência e grau de resistência.......... 59

4.2. Obtenção da linhagem resistente a benomy $1 \ldots . .60$

4.3. Obtenção da linhagem resistente a iprodione.. 64

4.4. Obtenção da linhagem duplo-resistente....... 64

4.5. Sensibilidade colateral............... 66

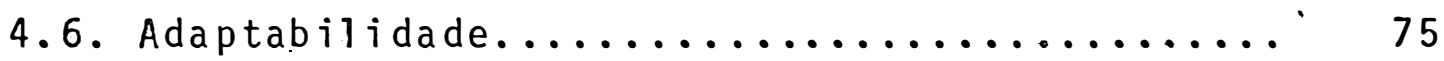

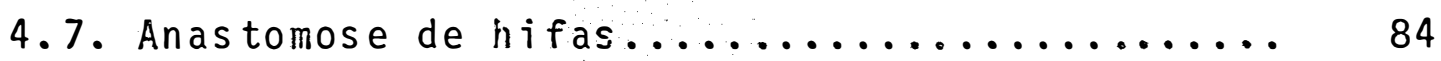

4.8. Coloração de nūcleos de conīdios........... 84

5. DISCUSSĂO.......................... 88

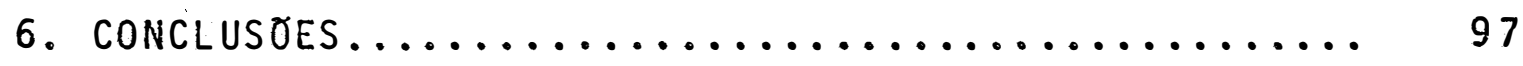

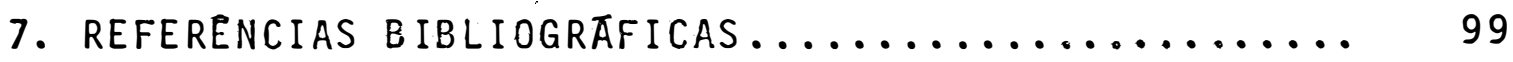


1. Origem dos isolados de Botrytis squamosa......

2. Efeito de dosagens de benomy 1 no crescimento micelial de isolados de Botrytis squamosa.....

3. Efeito de dosagens de benomy 1 no crescimento micelial de isolados de Botrytis squamosa.....

4. Efeito de dosagens de iprodione no crescimento micelial de isolados de Botrytis squamosa.....

5. Efeito de benomyl (1000 ppm) e iprodione (500 ppm) no crescimento micelial de linhagens duplo-resistentes obtidas a partir do isolado

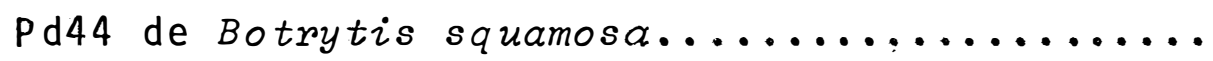

6. Efeito de dosagens de captafol no crescimento micelial de isolados de Botrytis squamosa......

7. Efeito de dosagens de captan no crescimento mi celial de isolados de Botrytis squamosa.......

8. Efeito de dosagens de dicioran no crescimento micelial de isolados de Botrytis squamosa......

9. Efeito de dosagens de mancozeb no crescimento micelial de isolados de Botrytis squamosa.....

10. Efeito de dosagens de procymidone no crescimen to micelial de isolados de Botrytis squamosa... 
11. Efeito de dosagens de propiconazol no crescimen to micelial de isolados de Botrytis squamosa....

12. Faixa de concentração de fungicidas que contēm - ED50 (dose do fungicida suficiente para inibir em $50 \%$ o crescimento micelial) dos isolados

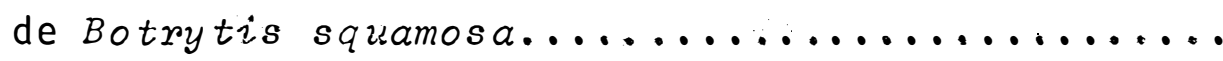

13. Efeito de fungicidas no crescimento miceliar de Iinhagens de Botrytis squamosa............

14. Crescimento micelial de Tinhagens de Botrytis

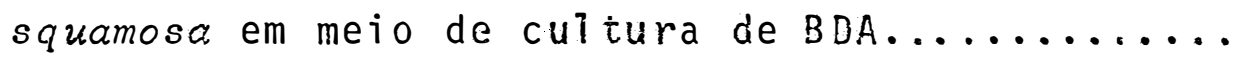

15. Produção de conídios de linhagens de Botrytis squamosa.

16. Patogenicidade de 7 inhagens de Botrytis squamo-

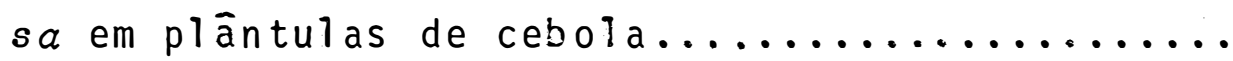

17. Patogenicidade de linhagens de Botrytis squamosa em discos de escama de butbos de cebola.....

18. Competição entre os isolados de Botrytis squamo sa resistentes ( $\mathrm{Pd} 27$ e $\mathrm{Pd} 67$ ) e sensivel (P4) a benomyl atravēs de transferēncias sucessivas de suspensões de conĩdios in vitro na ausēncia do

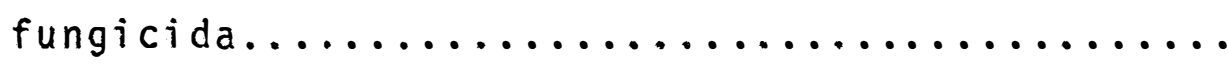

19. Competição entre os isolados de Botrytis squamosa resistentes $(P d 27, P d 64, P d 65, P d 67)$ e sens $\stackrel{i}{-}$ 
vel (P4) a benomyl atravēs de transferências su cessivas de inōculo em plāntulas de cebola, na ausência do fungicida (Experimento 1)..........

20. Competição entre os isolados de Botrytis squamosa resistentes ( $P d 27$ e $P d 67)$ e sensível

a benomy 1 através de transferências sucessivas de inōculo em plāntulas de cebola, na ausēncia

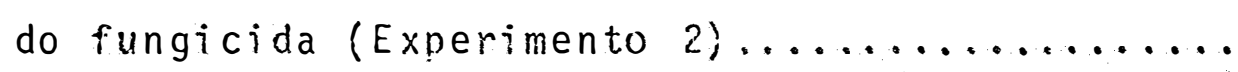

2i. Efeito de benomyi (1000 ppm) no crescimento mi celial de cinco gerações de subculturas monospō ricas do isolado Pd44 de Botrytis squamosa...... 85

22. Efeito de benomyl e iprodione no crescimento mi celiar de cinco gerações de subculturas monospö ricas da linhagem IUVI de Botrytis squamosa.....

23. Formação de anas tomose entre hifas de linhagens

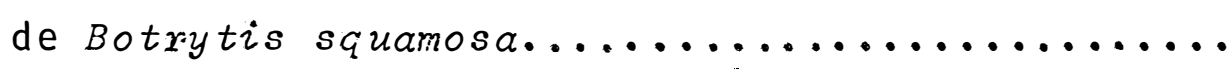


OCORRENCIA E ADAPTABILIDADE DE LINHAGENS DE BOTRYTIS SQUAMOSA RESISTENTES A FUNGICIDAS DO GRUPO DOS BENZIMIDAZOIS E DICARBOXIMIDAS

Autora: Raquel Ghini

orientador: Prof. Dr. Hiroshi Kimati

RESUMO

Isotados de Botrytis squamosa, causador da Queima das Pontas da cebola, foram testados quanto a resistência a benomyl a iprodiore atraves do mëtodo do fungicida incorporado ao meio de cultura. En culturas de cebola, nas quais foi utilizado benomy 1 , foram obtidos isolados resisten tes, apresentando crescimento micelial em meio de cultura de BDA contendo $1000 \mathrm{ppm}$ do fungicida. Em Jocais onde o benomy? não foi aplicado, os isolados apresentaram-se sensiveis ao produto, sendo o crescimentc inibido pela concentração de 1 ppm. Todos os isolados foram considerados sensiveis a iprodione, visto que apresentaram pouco ou nenhum crescimento mi celial em meio de cultura contendo $10 \mathrm{ppm}$ do fungicida.

Em condiçôes de laboratōrio, foram obtidas 1 i. nhagens iprodione - resistentes, a partir de uma benomy 1 sensível através de semeadura densa de conídios em meio de cultura contendo $500 \mathrm{ppm}$ do fungicida; linhagens com dupla- 
-resistência foram obtidas a partir da resistente a benomy atravēs de irradiação ultravioleta e transferēncias sucessivas em meios de cuitura com gradiente de iprodione.

As linhagens resistentes a benomyl, a iprodio ne e a iprodione + benomyl não tiveram alteradas suas sens bilidades ao fungicida propiconazol, porém houve uma tendēncia geral de se mostrarem mais sensiveis ao captan, captafol e mancozeb do que a linhagem sensivel. As linhagens resistentes a iprodione foram tambëm resistentes a procymidone e dicioran.

A adaptabilidade foi estudada aträvēs do cres cimento micelial, produção de conîdios, patogenicidade e com petição in vitro e in vivo das linhagens sensiveis e resis tentes a benomyl. As linhagens de $B$. squamosa resistentes a benomyl podem ser tão adaptadas quanto as sensíveis, ao passo que as resistentes a iprodione apresentaram-se menos adap tadas.

Testes de anastomose de hifas entre linhagens resistentes e sensiveis aos fungicidas benomy? e iprodione foram feitos. Isolados tanto sensiveis quanto resistentes se anastomosaram livremente, exceto o isolado Pdó, resistente a benomyl. O nümero de nūcleos/conídio em duas linhagens (uma sensīvel e outra resistente a benomy l) foi determinado, não tendo sido consiatadas diferenças; ambas apresentram atē 20 nūcleos/conỉdio. 
OCCURRENCE AND ADAPTABILITY OF Botrytis squamosa STRAINS RESISTANT TO BENZIMIDAZOLES AND DICARBOXIMIDES

\author{
Author: Raquel Ghini
}

Adviser: Prof. Dr. Hiroshi Kimati

SUMMIARY

I solates of Botrytis squamosa, causing agent of onion blast, were tested with respect to their resistance to benomyl and iprodione, through the method of fungicide incorporation in the growth medium. Resistant isolates were obtained from onion fields which had received treatment with benomyl. These isolates grew in PDA containing 1000 ppm of benomy1. Isolates from places where no beromyi treatment was applied were sensitive to 1 ppm of this fungicide. All isolates were corisidered to be sensitive to iprodione, since they showed little or no mycelial growth in a growth medium containing $10 \mathrm{ppm}$ of the fungicide.

Iprodicne resistant strains were obtained from sensitive ones, by plating a dense conidial susperision on a growth medium containing $500 \mathrm{ppm}$ of the fungicide. Strains with double-resistance were obtained from the benomylresistant one, by ultraviolet irradiation and sucessive transfers in culture media with a iprodione gradient. 
Resistant strains to benomyl, iprodione and iprodione + benomyl did not have their sensibility to propiconazole altered, but they showed a general tendency to be more sensitive to captan, captafol and mancozeb than the sensitive strain. Iprodione-resistant strains were also resistant to procymidone and dicloran.

Mycelial growth, conidial production, pathogenicity and in vitro and in vivo competition between the sensitive and resistant strains were the parameters used to study adaptability. Benomyl-resistant strains can be as adapted as the sensitive ones, whereas those resistant to iprodione ware less adapted.

Hyphal anastomosis tests between resistant and sensitive strains to benomyl and iprodione were performed. Sensitive and resistant strains anastomosed freely betwean themseives, with the exception of isolate Pd64, a benomyi-resistant one. Number of nuclei/conidium were determined for two strains (one sensitive to benomyl and the other not). There were no differences between themselves, both of them having up to 20 nuclei/conidium. 


\section{INTRODUÇÃO}

Antes do advento dos fungicidas sistêmicos, a resistência de fungos a fungicidas era de ocorrência rara em condições de campo. A inespecificidade dos produtos convencionais, is to é, a capacidade de interferir em numerosos pro cessos metabóilicos vitais, tornava difícil o surgimento de linhagens resistentes.

Com o crescente e intensivo uso dos fungicidas sistêmicos, holive o surgimento do problema, visto que tais produtos se caracterizam por uma a ta seletividade,agin do en poucos processos do metabolismo do patógeno qué, dessa forma, podem ser mais racilmente transpostos.

O surgimento de populações de fungos resis ten tes acarreta em descrédito e prejuizos para as indústrias agro quïmicas, perdas pará os agricultores e, consequentemente, maiores cus tos para o consumidor. A possibilidade de ocorrên cia de resistência produz iicertezas para as firmas fabrican tes durante o desenvolvimento de um novo produto. Apōs a introdução no miercado, se for cons tatado o problema, o uso do composto tem que ser restringido ou até mesmo abanḍnado,oca 
sionando graves dificuldades para o agricultor se não houver uma alternativa de controle adequada.

Quando ocorre falha no controle de uma doença, apōs repetidas aplicações de um fungicida, originariamen te eficiente, testes em laboratório ou em casa de vegetação podem comprovar se a causa foi o desenvolvimento de resistên cia ao produto em questão. Entretanto, as perdas seriam evitadas se, antes do aparecimento do problema, informaçóes fos sem obtidas em experimentos com fungos, in vitro ou in vivo, sobre as chances do surgimento de resistência na prática (DEKKER \& GEORGOPOULOS, 1982).

Face a esta situação, o estudo da ocorrência de resistência em Botrytis squamosa é de grande interesse pa ra o controle químico da Queima das Pontús dá cebola, visto ser uma doença de constatação sintomatológica frequente e que causa sérios prejuízos a esta cuitura (GHINI, 1984). Entre as hortaliças, a cebola apresenta considerävel consumo de fungicidas sistêmicos, sendo que o continuo uso desses pro dutos cria uma intensa pressão de seleção que, muito provavelmente, poderá resultar no surgimento de iinhagens resistentes.

O presente trabalho, visando estudar o proble ma apontado, tem por objetivos: 
1) Determinação da frequência e grau de resís tência a benomyl e iprodione de liniagens de Botrytis squamosa obtidas em culturas de cebola;

2) ob tenção, em condições de laboratório, de uma linhagem de $B$. squamosa resistente a benomy 1 e iprodione (duplo-resis tente);

3) Determinação da sensibil idade colatera? das linhagens de $B$. squamosa a outros fungicidas utilizados na cultura de cebola;

4) Es tudo da adaptabiridade das Tinhagens de B. squamosa resistentes e sensiveis a benomyl e iprodione. 
2. REVISAOO DE LITERATURA

\subsection{Resistēncia de fungos a fungicidas}

0 inĩcio da apiicação de fungicidas em larga escala para o controle de doenças està virculado à descoberta da calda bordalesa por Millardet em 1882, em Bordeaux, Tal mistura, composta por sulfato de cobre e cal hioratada, constituiu o principal fungicida utilizado por mais de 50 anos. Raraniente prob?emas com resisténcia a este fungicida, en condições de campo, foram reíatados (DEKKER \& GEORGOPOULOS, 1992). De modo geral, o mesmo ocorreu com os organo-mercuriais, introduzidos por volta de 1914, os ditiocarbamatos, in troduzidos na década de 1930, e vários outros fungicidas denominados convencionais, desenvolvidos posteriormente, segur do GEORGOPOULOS \& ZARACOVITIS (1967). Tocios esses compos tos têm em comum a característica de somente fornecer proteção à superfície da planta. Assim devem ser aplicados preventivamente. Esses fungicidas são inibidores de numerosos proces sos metabölicos vitais, compartilhados por todos os seres vi vos, portanto apresentam amplo espectro de ação. Dessa forma, devem ser insolūveis, não podendo penetrar, nem translo- 
car nos tecidos da planta, pois seriam altamente fitotóxicos (KIMATI, 19876).

Segundo DEKKER \& GEORGOPOULOS (1982), apÖS a Segunda Grande Guerra, iniciou-se o desenvolvimento de fungi cidas que penetrassem na planta, erradicando o patógeno apōs a infeç̧ão ou protegendo partes da planta que não entraram em contato direto com o fungicida. A partir do final da década de 1960 , segundo EDGINGTON et azizi (1980), com a ampla ace:tação de benomyl e carboxin, e a seguir de outros fungicidas sistēmicos, o controle químico de doenças de plantas assisriu grandes mudanças. Segundo KIRBY (1972), os fungicidas $s$ is têmicos, em uso na época, caracterizam-se por apresentar fun gi toxicidade direta; muito baixa a baixa solubilidade; penetração nos tecidos aēreos e raizzes, fassando para o xilema; movimento ascendente pela corrente transpiratória, acumilando-se nas margens das folhas; incapacidade de chegar a ōrgãos que não trarispiram e de reexportagão para regiöes de novos crescimentos; ausente ou reduzida transiocação descendente, via floema; e amplo ou estreito esfectro de ação.

Anaiisando as perspectivas dos fungicidas sis tēmicos apōs dez anos de uso, EDGINGTON et alii (1980) afirmaram que o número desses produtos aumentou de forma signifi cativa durante esse período, compreendendo aproximadamente 
um terço do total de fungicidas utilizados. Segundo KIMATI (1987a), essa escalada se deve ao fato de produtos sistémicos compartilharem características de maior especificidade e fungitoxidez inerente, bem como de penetração e translocação dentro da planta, tornando-os muito mais vantajosos do que os convencionais: maiores efeitos erradicantes, protetor, cu rativo e imunizantes; menores dosagens e nūmero de pulveri ża ções; menores problemas de fi totoxidez, de contaminação ambiental e de desequil îbrio biológico; e maior adequação para o uso em programas de manejo integrado.

Entretanto, GEORGOPOULOS (1969) arertou que problemas com resistëncia de fungos a fungicidas deveriam ser mais frequentes e mais sérios com a utilização dos novos pro dutos seletivos do a ue com os convencionais. Segundo TOLEon (1974), DEKKER (1976) e DELP (1980), tal fato se concretizou com os numerosos relatos de resisténcia a fungicidas ocorridos des ie então.

A seletividade, que permite um fungicida atuar sistemicamente, aumentando tanto a sua eficiēncia, è, ao mes mo tempo, causa de sua vulnerabilidade, segundo KIMATI (1987a). DEKKER (1977) explica que mudanças genēticas que resultam na resisténcia de um patógeno a fungicidas ocorrem con maior facilidade com compostos que atuam primariamente em um ou 
poucos passos do metabolismo da cēlula do fungo do que com fungicidas que interferem em muitos passos do processo metabōlico. Assim sendo, DELP (1980) afirma que, atē 1970, devido à predomināncia de fungicidas convencionais ou inespecĩfi cos, os casos de resistēncia relatados no campo limitavam-se a menos de 10 gēneros de fungos; em contraposição, em 1980, com o intensivo e extensivo uso de fungicidas sistēmicos, es se nümero era de, aproximadamente, 35 gēneros.

No Brasil, poucos trabalhos foram deserivolvidos quanto a resistēncia de fungos a fungicidas. o estudo da ocorrēncia e adaptabilidade de linhagens de B.squamosa resistentes a benzimidazóis e dicarboximidas pode constatar um sério problema que compromete o uso desses dois grupos de fungicidas utilizados no controle químico da Queima das Pontas da cebola.

\subsection{Benzimidazóis}

Segundo DAVIDSE (1982), dos fungicidas s is têmicos, os benzimidazöis são os mais conhecidos devido às suas propriedades sistēmicas, eficācia no controle de importantes doenças e tambēm pelos problemas que ocorrem com o surgimento de resistência.

o primeiro composto desenvolvido, segundo 
DAVIDSE (1982), foi o thiabendazol, o qual foi introduzido em 1961 , como um vermífugo utilizado em medicina humana e veterināria. A seguir, foram introduzidos o benomyl, carbendazim e fuberidazol. Os tiofanatos, introduzidos em 1971, são fre quentemente incluídos neste grupo já que, sob condições naturais, são convertidos em compos tos classificados como benzimidazóis. Fenbendazol, mebendazol, oxibendazol e parbenda201 possuem propriedades anti-helmínticas e são utilizados em medicina veterināria, ao passo que nocodazol, segundo DAVIDSE (1982), foi descrito como sendo ativo contra tumores em mamí feros, incluindo o homem.

0 transporte dos benzimidazóis nas plantas se dá via xilema, segundo EDGINGTON (1981), sendo a absorção pe 1 as raízes um processo passivo. o carbendazim pode entrar no floema, mas é devolvido à corrente transpiratória sem haver transporte descendente significante, exceto quando altas dosagens são aplicadas. 0 thiabendazol é o benzimidazol que apresenta movimento mais lento e carbendazim, o mais rápido.

Segundo KIMATI (1980), o amplo espectro de ação dos fungicidas des te grupo tem um valor mui to grande pa ra a fi topatologia porque abrange gēneros de fungos que ocasionam graves prejuízos em um grande número de importantes culturas, tais como oídios, antracnoses, cercosporicaies, sar 
nas, mofos cinzentos (Botrytis) e bolores (Eenicizlium).

As investigações de Bollen e Fuchs (1970) (1), citados por KAARS SIJPESTEIJN (1977), sobre o espectro de ação de benomyl, revelaiam uma notável seletividade dentro do grupo dos Ascomicetos: enquanto muitas espëcies estudadas são altamente sensĩveis, as pertencentes a Porosporae ou Annellosporae provaram ser insensiveis. Os oomicetos e outros ficomicetos foram tambēm insensĩveis. EDGINGTON et aliz (1971) obtiveram resultados semelhantes quanto ao espectro fungitóxico dos benzimidazōis e relataram que Botrytis sp. foi altamente sensĩvel, sendo que a concentração que inibia $50 \%$ do crescimento em meio de cultura foi de $0,4 \pm 0,05 \mathrm{ppm}$.

2.2.1. Modo de ação e seletividade

CLEMONS \& SISLER (1969) e Selling et alii (1970)

(2), citados por DAVIDSE (1982), provaram que benomy 1 e tiofanato metīlico, respectivamente, são transformados em carbendazim e nesta forma eles atuam. Assim sendo, vārios estu-

(1) BOLLEN, G.J. \& A. FUCHS. On the specificity of the in vitro and in vivo antifungal activity of benomy1. Netherlands journal of Plant Patrology 77, 83. 1970 .

(2) SELLING, H. A.; VONK, J. W.; RAARS SIJPESTEIJN, A. Transformation of the systemic fungicide methyl thiophanate into 2- benzimidazole carbamic acid, methyl ester. Chemistry and Industry: 1625, 1970. 
dos têm mostrado que os benzimidazōis compartilham de um mes mo modo de ação, isto é, interferem na mitose dos fungos, agindo principalmente no crescimento micelial (DAVIDSE, 1982) e com pouco efeito na germinação de conídios.

Uma proteína que se liga ao carbendazim foi encontrada em extrato de micēlio de Aspergizzus niduzans, por DAVIDSE \& FLACH (1977), com propriedades bioquímicas caracte rísticas da tubulina (unidade que compõe os microtúbulos do fuso mitótico). Esses autores provaram que o carbendazim se liga à tuburina, no mesmo local de ligação da colchicina, e impede a reunião das tubuitinas para formar o fuso mitótico, consequentemente impedindo a divisão celular.

0 sistema de fuso mitótico está presente em todas as células de eucariotos, mas nem todos são igualmente sensíveis aos benzimidazóis, o que implica em uma seletividade, por exemplo, entre a planta hospedeira e o patógeno. DAVIDSE \& FLACH (1977) provaram que a afinidade do benzimida 201 com a tubulina é o principal fator que determina a ativi dade do fungicida nos organismos. Assim, quanto maior a afinidade de ligação do benzimidazol com a tubulina, mais sensí vel é o organismo ao fungicida. Da mesma rorma, uma mutação que reduza a afinidade de ligação da tubulina com o benzimidazol, sem afetar o funcionamento normal da tubulina, dá or $\underline{i}$ gem a una linhagem resis tente. 
Entretanto, segundo DAVIDSE (1982), a existên cia de outros mecanismos de resistência não pode ser inteira mente descartada. Um decréscimo na permeabilidade da cérula a carbendazim foi sugerido por NACHMIAS \& BARASH (1976), como mecanismo de resistência a benzimidazóis em Sporobolomyces roseus. LAMBERT \& WUEST (1976) sugerem que a resistência a benomyl em Verticillium malthousei está associada à produção de um ācido não identificado que reduziria a atividade do fungicida. Estudando os mecanismos de resistência de Botmytis cinerea a carbendazim, TRIPATHI \& SCHLOSSER (1982) verificaram que a linhagem resistente absorvia $44 \%$ menos carbendazim e sua tubulina era capaz de 1 igar com $73 \%$ menos fungicida que a linhagem sensīvel, sendo a linião dos dois fatores responsāvel pela resistência.

\subsubsection{Resistência}

Segundo DAVIDSE (1982), o desenvolvimento de resistência a benomy e outros benzimidazóis tem sido reportado para uma larga gama de patógenos, em condições de laboratório ou de campo, tanto na agricultura, quanto na medicina veterināria. DELP (1980) afirmou que até aquela data, a resistência de patógenos a benzimidazóis foi encontrada em 16 gèneros de fungos, sendo o primeiro relato realizado por SCHROEDER \& PROVVIDENTI (1969), com oidio do pepino resisten 
te a benomy 1 .

A resistência de Botrytis cinerea a benomy? foi primeiramente relatada, em condições de campo, em ciclame, por BOLLEN \& SCHOLTEN (1971). A seguir, numerosos relatos foram feitos em diversas culturas, como por exemplo, em crisântemo, por WATSON \& KOONS (1973); pepino,por IIDA (1975); alface, por MILLER \& FLETCHER (1974); em tomate, por MILLER \& FLETCHER (1974) e FLETCHER \& SCHOLEFIELD (1976); morango, por JARVIS \& HARGREAVES (1973) e no Brasil, por CABRINI(1985); em Leucospermum cordifolium, por CHO (1977); em macieira, fei joeiro e videira, por PEARSON et aliil(1980); essências florestais, por GILLMAN \& JAMES (1980); em eucalipto, por GHINI \& KRUGNER (1987), no Brasi1; e em cebola, por PRESLY \& MAUDE (1980b): E interessante salientar que PEARSON et alii(1980), estudando linhagens de $B$. cinerea resistentes a benomyl, isoladas de macieiras, feijoeiros e videiras, provaram que o fun go resistente em uma dessas culturas era patogênico às demais, fato que agrava a situação.

Para DELP (1980), os benzimidazóis representam o inĩcio dos graves problemas com o surgimento de resís tência na histōria dos fungicidas. O mesmo autor explica que is to ocorreu não somente porque os benzimidazóis foram extensiva e intensivamente utilizados, mas também porque são 
inibidores de um sîtio específico do metabolismo do patōgeno e muitos fungos possuem linhagens resistentes em sua popuração naturaì, que não sofreu pressão de seleção do fungicida, como ocorreu com B. cinerea isolado de plantas ornamentais (BOLTON, 1976), com Ceratocystis ulmi (SCHREIBER \& TOWNSEND, 1976) e Verticillium malthousei (WUEST et alii, 1974)

Via de regra, quando os problemas com resistência ocorrem, as 1 inhagens resistentes a um benzimidazol são resistentes aos outros do mesmo grupo, is to é, apresentam re sistência cruzada (MILLER \& FLETCHER, 1974; POLACH \& MOLIN, 1975; RUPPEL, 1975; DAVIDSE, 1982 e LEROUX \& CLERJEAU,1985). 0 mecanismo responsāvel por esta correlação,segundo GEORGOPOULOS (1982a), deve-se ao fato dos benzimidazóis compartilharem de um mesmo modo de ação. Entretanto, hā a exceção de TUYL et alii (1974) que observaram a ocorrência de mutantes de Aspergizlus niduzans, em muito baixa frequência, obtidos em meio de cultura contendobenomyl, que eram sensíveis a thiabendazol, apesar da resistência a benomyl, e mutantes re sistentes a thiabendazor que eram mais sensĩveis a benomy 1 do que a linhagem servagem.

LEROUX \& CLERJEAU (1985) observaram uma resis tência cruzada negativamente correlacionada entre fenilcarba matos (barban ou chlorbufam) e benzimidazóis, em linhagens 
de Botrytis cinerea isoladas de videiras.

0 desenvolvimento de linhagens duplo. - resistentes, isto é, apresentando resistência a benzimidazōis e outros fungicidas foi constatada em diversas ocasiões: CHASTAGNER \& OGAWA (1979) obtiveram linhagens de B. cinerea resistentes a benomyl e dicloran in vitro; PEPIN \& MacPHERSON (1982) isolaram $B$. cinerea resistente a benomyl e captan em condições de campo; com os dicarboximidas foram observadas in vitro linhagens duplo-resistentes de $B$. squamosa por PRESLY \& MAUDE (1982) e em condições de campo, com linhagens de B. cinerea, por LEROUX \& CLERJEAl] (1985), GULLINO \& GARI BALDI (1986) e NORTHOVER \& MATTEONI (1986).

Quanto a genētica da resistēncia, segundo GEORGOPOULOS ( $1982 b)$, o melhor exemplo disponível sobre a ação de um gene que controla a sensibilidade a um fungicida de uso agrícola é o gene que proporciona resistência a benzi midazóis em Aspergizzus niduzans, devido aos intensos estudos realizados. TUYL (1977) mostrou que mutações no gene ben - A seriam responsāveis pelo desenvoivimento de linhagens de A. niduzans resistentes a benzimidazóis.

0 ben-A codifica a B-tubuitina, uma das sub-uni dades da molécula de tubulina. Mutações nesse gene afetam as 
propriedades eletroforēticas da B-tubulina e, ao mesmo tempo, a habilidade da proteína se ligar com o carbendazim, a qual é inversamente correlacionada com a resistēncia ao fungicida.

Outros genes conferindo resistēncia aos benzi midazōis foram reconhecidos em vārios outros fungos, embora sua ação não tenha sido es tudada no nível bioquímico. A análise genética de mutantes resistentes a benomyl de Neurospora crassa, realizada por BORCK \& BRAYMER (1974), sugeriu que um úni co gene dominante é responsāvel pela resistência. BRASSIER \& GIBBS (1975), estudando Ceratocystis ulmi, concluiram que a resistência a carbendazim, provavelmente, era conferida por um ünico gene. Em pesquisa realizada com Venturia inaequalis, MARTIN (1982) observou que a resisténcia a benomyl é controlada por um só gene e KATAN et alii (1983) constataram, apōs diversos cruzamentos entre 1 inhagens, que o nível de resistência a benomyl era controlado por mutações em quatro alelos de um gene de segregação mendeliana, sendo que não foram observados efeitos de genes modificadores ou componentes ci toplasmáticos.

A adaptabilidade das linhagens resistentes a benzimidazóis parece variar largamente, mas a maioria dos relatos indica que a resistência não está ligada a uma redu 
ção da adaptabilidade e se mantēm estāvel em vārios patōgenos, por longos períodos, mesmo na ausência do fungicida.

Um dos primeiros casos de constatação de resistência a benzimidazóis, a nīvel de campo, ocorreu com Cercospora beticoza em beterraba açucareira na Grécia. No início, segundo GEORGOPOULOS \& DOVAS (1973), o benomyl apresentou excelentes resultados, controlando a doença e porisso passou a ser usado exclusivamente em diversas regiões da Grē cia, durante 1970 e 1972. Entretanto, em 1972 a doença aumen tou rapidamente e não foi controlada devido ao surgimento de resistencia aos benzimidazōis. DOVAS et a $i \mathbf{i}$ (1976) conclui ram que a adaptabilidade das 1 inhagens resistentes não diferia das sensíveis, visto que sua frequência ra população per manecia constante, mesmo na ausencia do fungicida.

Estudando o mesmo problema nos Estados Unidos, RUPPEL (1975) concluiu que as linhagens de Cercospora beticola resistentes a benzimidazōis não diferiam das sensĩveis quanto ao crescimento e esporulação in vitro ou pátogeni $i$ idade e esporulação in vivo. Mais tarde, RUPPEL et alii (1980) verificaram que as 1 inhagens resistentes apresentavam um alto grau de persistência na ausēncia de benomy 1 , mes 
mo em campos onde outros fungicidas estavam sendo usados.

Uma alta persistência da linhagem resistente em relação à sensĩvel tambēm foi observada por MILLER \& JEVES (1979), que relataram a ocorrēncia de linhagens de $B$. cinerea resistentes a benomy 1 , em tomateiros cultivados comercialmente em estufas, très ou mais anos após o fungicida deixar de ser utilizado. Esses autores enfatizam a persistência das linhagens resistentes comparando seus resultados com os obtidos por FLETCHER \& SCHOLEFIELD (1976). No levantamento reaiizado em 1977, MILLER \& JEVES (1979) constataram que 64,3\% dos isolados eram resistentes, enquanto que FLETCHER \& SCHOLEFIELD (1976), nas mesmas condições, em 1974, observaram que a frequência se manteve ao redor de $49,6 \%$.

Resultados semelhantes iambēm foram obtídos no estudo da estabilidade da resistēncia a benzimidazóis em populações de $B$. cinerea em videiras na Suíça, reaíizado por SCHUEPP \& KUNG (1931). A frequência das linhageris resistentes decresceu somente 5 pontos percentuais após quatro anos sem utilizar tais fungicidas. Uma alta adaptabilidade da linhagem de $B$. cinerea resis tente a benzimidazóis em videiras tambēm foi relatada por LEROUX \& CLERJEAU (1985).

No estudo da competição in vivo entre uma 1 inhagem de Venturia inaequalis resistente e uma senșivel a be 
nomyl, MARTIN (1982) constatou que a linhagem resistente pre dominou apōs algumas gerações, sendo es te resultado obtido para diversas linhagens testadas e tambēm na confrontação de uma linhagem resistente e uma população sensível (mistura de linhagens sensiveis). Entretanto, a concentração de inóculo total e a relação entre as concentrações das linhagens influenciaram na velocidade de desaparecimento da linhagem menos competitiva, no caso, a sensível.

Todavia, nem sempre a linhagem resistente é tão adaptada quanto a linhagem sensível. JORDAN \& RICHMOND (1974) observaram que linhagens de $B$. cinerea resistentes a benomyl, apresentando diferentes velocidades de crescimento em meio de cultura, diferiam quanto a patogenicidade. Da mes ma forma, GEESON (1976) encontrou considerāvel variação no diàmetro da colónia, esporulação e produção de esclerōdios de linhagens de $B$. cinerea resistentes a carbendazim na ausência do fungicida.

SOULIER (1984), es tudando a competição in vivo entre uma linhagem de Venturia inaequalis resis tente a benzi. midazóis. (BAT) e duas linhagens sensiveis ( $R_{2}$ e 106), atravēs de inocurações sucessivas de misturas de conídios, obteve resultados diferentes para cada uma das 1 inhagens sens $\mathbf{i}-$ veis. Na competição entre BAT e 106, houve o desaparecimento 
da linhagem sensĩvel apōs duas gerações na planta hospedeira, ao passo que na confrontação DE BAT e $R_{2}$, a linhagem resistente teve sua frequência reduzida e mantida ao nível de $3 \%$.

2. 3. Dicarboximidas

0 termo dicarboximida tem sido amplamente us a do, segundo BEEVER \& BYRDE (1982), para os fungicidas vinclo z.olin, iprodione e procymidone, sendo que o primeiro dicarbo ximida a ser desenvolvido, dichlozoline, foi retirado do mer cacio ìogo após a sua introdução. Entretanto, BAILLY \& DUBOIS (1981) incluem tambēm nesse grupo de fungicidas: captan, foipet, captafol e ditalimphos, sendo esta classificação pouco utili zada.

Os dicarboximidas têm sido empregados no controle de doenças causiadus por patógenos taxonomicamente rela cionados (Sclerotiniaceae), incluindo Sclerotinia, Monizinia e Botrytis. Entre os dicarboximidas, iprodione $\bar{e}$ recomendado para o controle de importantes doenças, tais como o mofo cinzento em morangos, causado por Botrytis cinerea; a podridão parda de frutos, causada por Monizinia, a podridão branca do alho, causada por Sclerotium cepivorum; e Alternaria em cebola e cenoura (KIMATI et aiii, 1986). 
Segundo EDGINGTON (1981), embora os dicarboxi midas não sejam considerados sistêmicos, inclusive pelas indūstrias produtoras dos fungicidas, hā evidências de que são sistêmicos. Hisada et alii (1977) (1), citados por BEEVER \& BYRDE (1982), demonstraram que procymidone é translocado em pepino, tanto em movimento acropētalo, quanto basipëtalo. Segundo BEEVER \& BYRDE (1982), iprodione, relatado inicialmen te como não sis têmico, é translocado em batata.

2.3.1. Modo de ação

Apesar das intensas investigações, conforme BEEVER \& BYRDE (1982), o modo de ação dos dicarboximidas per manece indefinido. As semelhanças quanto às características químicas, os efeitos similares em fungos e o modelo de resis tência cruzada dos dicarboximidas suportam a proposição de que todos os fungicidas deste grupo compartilham um mesmo modo de ação. Ainda segundo BEEVER \& BYRDE (1982), alguns a u tores erroneamente sugerem que iprodione difere dos outros dicarboximidas, is to porque em solução etanōlica ou metanólica, iprodione é transformado em um isômero muito menos ati

(I) HISADA, Y. KATO, T. ; KAWASE, Y. Sistemic movement in cucumber plants and control of cucumber gray mold by a new fungicide, S7131. Netherlands Journal of Plant Pathology 83 (supp1. 1): 7178. 1977 . 
vo (COOKE et alii, 1979) e estas soluções são frequentemente utilizadas em testes biológicos.

FRIETZ et alii (1977), estudando o mecanismo de ação de procymidone e vinclozolin em Botrytis cinerea,con cluiram que hà uma forte inibição no crescimento micelial e germinação de conídios; pouco efeito na respiração; pouco efeito na sîntese proteíca; pouca influência no metabolismo do esterol, entretanto, com algum aumento na fração dos āci dos graxos livres; e forte redução na taxa de incorporação de uridina radioativamente marcada nos ácidos ribonucleicos.

Na comparação do mecanismo de ação de vinclozolin, procymidone e iprodione em Botrytis cinerea, PAPPAS \& FISCHER. (1979) não conseguiram determinar o modo de ação prị mário destes fungicidas. Os resultados mostraram que os dicarboximidas têm pouco efeito na germinação de conídios e o crescimento micelial é afetado, sendo que, em adição à redução no diāmetro da colōnia, houve um decrēscimo visível na quantidade de micēlio aéreo. Nenhum composto afetou a respiração, a permeabilidade das membranas e a sintese proteica e de RNA, exceto iprodione que reduziu a incorporação de timina radioativamente marcada na sintese de DNA. Os dicarboximi das alteraram a sintese de lipídios, sendo que vinclozolin e procymidone reduziram a sintese de trigliceratos e iprodione 
reduziu a sintese do esterol. A sintese de quitina foi pouco afetada.

Segundo PAPPAS \& FISHER (1979), os resultados divergentes quanto ao modo de ação dos dicarboximidas são,pro vavelmente, devido a diferenças nas técnicas utilizadas, por exemplo, a inibição do crescimento micelial de procymidone é muito influenciada pela densidade de inōculo.

GEORGOPOULOS et alii (1979) relataram que os dicarboximidas aumentam a frequência de recombinação mi tōtica em Aspergizlus niduzans, assim sua ação nos cromossomos è a principal razão da fungitoxicidade, atuando de forma semeThante aos fungicidas pertencentes ao grupo dos hidrocarbone tos aromáticos (dicloran e quintozene). Para BEEVER \& BYRDE (1982), esta conclusão é prematura, visto que tais efeitos podem ser secundārios ou refletem a ação em somente um dos numerosos sĩtios.

\subsubsection{Resistência}

Segundo BEEVER \& BYRDE (1982), linhagens resistentes a dicarboximidas têm sido obtidas tanto em condições de campo quanto de laboratório. Todavia, são poucos os exemplos de falha no controle de doenças devido a resistén cia do patōgeno a estes fungicidas. Para POMMER \& LORENZ(1982), 
experimentos em laboratōrio têm mostrado que fungos do gêne ro Botrytis se tornam resistentes a crescentes concentrações de dicarboximidas com ou sem o uso de agentes mutagènicos, En tretanto, o räpido desenvolvimento de resistência.in vitro não implica necessariamente em um rápido surgimento de resis tência em condições de campo. As observações têm indicado que a resistência aos dicarboximidas não ocorre tão "rapidamente em condições naturais, como ocorre nos laboratórios.

Com o objetivo de avaliar a possibilidade de ocorrência de resistência a dicarboximidas de Botrutis cinerea isolado de videiras, LEROUX et alii (1977) selecionaram in vitro linhagens resistentes a iprodione (30 ppm), vinclozolin (30 ppm) e dicloran (100 ppm) a partir de linhagens sensiveis e resistentes a benzimidazōis, com ou sem exposição à luz uitravioleta. Os resultados mostraram que as linhagens resistentes aos dicarboximidas podem ser tão vigorosas e patogènicas quanto as sensíveis. A frequēncia de obtenção de linhagens resistentes a dicloran, vinclozolin e iprodione, a partir da sensivel a benomyl, foi de 2 a $5.10^{-7}$ e 30 a $140.10^{-7}$, sem e com exposição à luz ultravioleta, respectivamente.Com a linhagem resistente a benomy 1 , a frequência foi inferior a $10^{-7}$. 
VASSEY (1979) obtiveram 1 inhagens de $B$. tulipae resistentes a iprodione e vinclozolin, após a transferência de conídios para meio de cultura de BDA contendo $50 \mathrm{ppm}$ dos fungicidas, nas frequēncias de $1,8 \cdot 10^{-6}$ e $4,0 \cdot 10^{-5}$, respectivamente. A taxa de crescimento da linhagem resistente foi aproximadame $\underline{n}$ te a metade da sensível em meio de cultura de BDA sem fungicida. As linhagens resistentes esporulavam e produziam escle rōdios e eram tão patogènicas quanto as sensíveis.

Apesar de não terem sido relatados casos de resistência a dịcarboximidas para Botrytis squamosa em culturas de cebola, PRESLY \& MAUDE (1982) estudaram a possibili dade de surgimento do problema a partir de linhagens resistentes e sensiveis a benomy?. Foram obtidas, in vitro, 1 inh $\underline{a}$ gens capazes de crescer em meio de cultura contendo 4,20 , 100 , 500 e 2500 ppm de iprodione. Estas linhagens apresenta ram menor crescimento micelial na ausência do fungicida, menor capacidade de esporutação e foram menos patogênicas que as 7 inhagens sensĩveis. Entretanto, a resistência não foi perdida apōs diversas transferēncias na ausēncia do fungicida.

A possibilidade de desenvolvimento de resistência a dicarboximidas tambēm foi estudada em linhagens que adquiriram resistência em experimentos realizados com subs- 
tratos naturais.

DENNIS \& DAVIS (1979) isolaram linhagens de B. cinerea resistentes a iprodione e vinclozolin em algumas lesões com lento desenvolvimento, em morangos utilizados num experimento cuja finalidade era avaliar a eficiência dos dois fungicidas em pré e pós-colheita, durante dois anos. A concentração que reduzia o crescimento micelial do isolado resistente em $50 \%$ variou de 160 a 480 ppiii para iprodione e 150 a 650 ppm para vinclozolin, sendo que todos os isolados resistentes eram capazes de crescer em meio de BDA contendo 10000 ppm de iprodione ou 1000 ppm de vinclozolin.Baixas con centrações dos fungicidas estimulavam o crescimento das 1inhagens resistentes. Transferências sucessivas em meio de cul tura sem os fungicidas ocasionaram perda da resisténcia. os autores concluiram que a eficiência destes produtos no controle da doença nos experimentos realizados poderia ser devi do a baixa frequéncia das linhagens resistentes ou à instab lidade da resistência na ausēncia dos fungicidas ou pela menor patogenicidade das 1 inhagens resistentes.

Um isolado de $B$. cinerea resistente a vinclozolin, procymidone e iprodione foi obtido por PAPPAS et a $i$ i (1979), em morangos inoculados com um isolado resistente a benomyl e tratados com iprodione. 0 isolado resistente a di 
carboximidas manteve a resisténcia a benomyl, alēm de apresentar resistência a quintozene e dicloran, entretanto, permaneceu sensivel a captan, thiram, chlorothalonil, dichlofluanid, triadimefon, imazalil e prochloraz.

Testes em morangos destacados mostraram que a linhagem resistente a iprodione era tão patogênica quanto a sensível. Não foi observada diferença na quantidade de fung $\underline{i}$ cida absorvido pelas linhagens sensiveis e resistentes. Ha ausência do fungicida, tambēm não foi observada diferença no crescimento micelial e germinação de conídios, entretanto, o crescimento micelial do isolado sensivel foi completamente ini bido com 2 ppm de iprodione e a germinação de conídios foi reduzida $65 \%$ com $20 \mathrm{ppm}$. Com esses resultados, PAPPAS et alii (1979) concluíram que a partir de isolados resistentes a beno mil constatados em alta frequéncia por outros autores em condições de campo, é possível o surgimento de linhagens apre sentando dupla-resisténcia a benzimidazóis e dicarboximidas.

Para POMMER \& LORENZ (1982), apesar de não te rem sido relatados sērios prejuízos com o surgimento de resistēncia aos dicarboximidas em condições de campo, uma situação diferente parece estar ocorrendo em culturas protegi das por es tufas. HARTILL et alii (1983) explicam que a barreira física da estufa dificulta a entrada de conídios, portanto a 
competição entre as linhagens não ē tão intensa quanto fora da estufa. Assim, uma vez que a população resistente se desenvolveu em uma estufa, ela pode ser mais estāivel do que uma população similar em condições de campo.

\section{PANAGIUTAKU \& MALATHRAKIS (1981) E KATAN (1982a)}

realizaram levantamentos sobre a ocorréncia de $B$. cinerea,cau sador do mofo cinzento em diversas plantações comerciais em estufas, resistentes a dicarboximidas na Grécia e em Is rae?, respectivamente. Ambos os 1 evantamentos constataram a presen ça de 1 inhagens resistentes reduzindo a eficäcia do fungicida, mas foram testados baixos níveis de resistência $(2,5$ ppm e 5 ppm, respectivamente).

Estudando mais detähadamente o problema, KATAN (1982b) verificou que os conidios de $B$. cinerea resistentes a iprodione e vinclozolin, isolados de pepino, tomate, morán go e berinjela cultivados em estufa, germinavam normalmente em meio de cultura de B contendo $100 \mathrm{ppm}$ de vinclozolin. De modo geral, as 1 inhagens resistentes apresentavam uma taxa de crescimento linear 25 a $30 \%$ menor do que as sensiveis em meio de cultura de BDA. As concentrações que reduziam a taxa de crescimento 1 inear das 7 inhagens resistentes em $50 \%$ variavam de 1,0 a 4,2 ppm para vinclozolin, iprodione e procymidone.

$\mathrm{Na}$ Nova Zelãndia, onde os dicarboxịidas eram 
amplamente utilizados des de 1978, HARTILL et aizi (1983) cons tataram que aplicações frequentes de vinclozolin e procymidone faliaram no controle de $B$. cinerea em folhas e frutos de tomate e pepino cultivados comercialmente em estufäs, em 1980. Testes de laboratōrio comprovaram que os isolados eram capázes de crescer em meio de cultura contendo dichlozolinate, iprodione, procymidone, vinclozolin, dicioran, quintozene e benzimidazōis.

No mesmo país, BEEVER \& BRIEN (1983) realizaram um levantamento da resistência de $B$. cinerea a dicarboxi. midas em diferentes culturas. Em planiações de videira, kiwi, morarigo, e "boysenberry", Tinhagens resistentes foram ob tidas em somente duas das 18 propriedades examinadas, uma em videira e outra em morangueiro, sendo que em nenhum caso, apa rentemente, houve perda de controie da doença. Emi plantios comerciais de tomate, feijão-vagem e pepino, em estufas, $7 i-$ nhagens resistentes a dicarboximidas foram isoladas nas sete propriedades visitadas, com alguns casos de fracasso no controle da doença devido a resistência ao fungicida. Entretanto, o grau de resistēncia erabaixo (dose necessária para inibir $50 \%$ do crescimento radial menor que $5 \mathrm{ppm})$. Os auto res observaram uma correlação positiva entre a frequência de uso de dicarboximidas e a ocorrência de resistência, embora em plantações fora de estuf́as näo foram verificados casos de 
resistência apesar do intensivo uso dos fungicidas.

Para estudar o desenvolvimento de limagens de B. cinerea resistentes a dicarboximidas em videiras na Fran ça, LEROUX \& CLERJEAU (1985) dividiram os vinhedos em três grupos, sendo o primeiro localizado na região de Champagne; o segundo em Alsace, Burgundy e Lovre Vall ey e o terceiro, no sul da França. As plantações de videiras do primeiro grupo receberam pelo menos quatro tratamentos com dicarboximidas por ano, entre 1977 e 1982. Entretanto, desde 1980 es tes fungici das apresentaram-se menos efetivos, sendo que em 1982, o mofo cinzento não foi controlado cievido ao desenvolvimento de resistência a dicarboximidas. Face a esta situação, tais pro dutos não foram recomendados em 1983. Apesar disso aiguns vi ticultores continuaram a utilizä-ios. Nesse ano houve uma redução na frequência de linhagens resistentes a dicarboximi das, no entanto, insuficiente para utiliza-jos na estação seguinte.

No s egundo grupo, LEROUX \& CLERJEAU (1985) i il cluiram vinhedos que receberam dois tratamentos à base de di carboximidas por ano, desde 1977 . Neste grupo, os resultados foram contraditörios, sendo que o tratamento foi eficien te em alguns casos e não em outros. No terceiro grupo, as plan tações de videiras não estavam afetadas por linhagens resis tentes, visto que elas não recebiam mais do que uma aplica 
ção anual de dicarboximidas. Com es tes resultados, os autores sugerem estratēgias diferentes para cada regiăo da França,visando reduzir ou prevenir o problema de resistência.

Em um levantamento semeihante sobre a ocorrên cia de linhagens resistentes a dicarboximidas em vinhedos de Ontario (Canadā), NORTHOVER \& MATTEONI (1986) detectaram a presença de linhagens de $B$. cinerea combaixo nível de resistência (2- $4 \mathrm{ppm})$ a iprodione em piantaçáes que receberam dez ou mais aplicações desse fungicida ou vinclozolin, du rante quatro anos. Baixo nível de resistencia a iprodione tam bën foi constatado em culturas comerciais em asturas, apōs o uso de iprodione por cinco anos, havendo uma correlação pos tiva significativa enire o uso do fungicida e a presença de linhagens resistentes.

Na I tälia, em um programa de monitoramento de resistēncia a fungicidas em videiras, iniciado em 198?, GULLINO \& GARIBALDI (1986) constataram a presença de Iinhagens de $B$. cinerea resistentes a dicarboximidas em 21 a $50 \%$ dos campos monitorados, entretanto, em baixa incidência dentro de cada campo. A resistëncia a dicarboximidas foi monitorada utilizando duas concencrações de vinclozolin (3 e 30 ppm) pa ra selecionar linhagens combaixo e alto nivel de resistência. Os autores concluiram que os dicarboximidas continuam sen 
do efetivos em condições de campo, entretanto, frente aos problemas com resistência a esses fungicidas observados em outras culturas ou outros países e o baixo, mas constante, a $\underline{u}$ mento na incidência de resisténcia, foi sugerido um cantínuo monitoramento da popuração do patōgeno.

Com a finalidade de estudar a adaptabilidade de 1 inhagens de $B$. cinerea resistentes a dicarboximidas, DAVIS \& DENNIS (1987a) analisaram isolados ob tidos em condições de campo e de laboratörio. Foram consideradas resistentes as 1 i nhagens que crescessem em meio de cultura contendo 50 ppm de iprodione ou vinclozolin. Seis dos oito isolados de morangli nho mantiveram a resistēncia aos dicarboximidas durante 40 sub-cultivos na ausēncia do fungicida, durante 6 meses, sendo portanto considerada uma resistência estãvel. Entretanto, segundo os autores, as linhagens de $B$. cinerea resistentes a dicarboximidas pareciam ser de pouca importância prätica naquela ocasião, visto apresentarem ocorrência esporädica. A reduzida frequéncia de linhagens resistentes é explicada por DAVIS \& DENNIS (1981a) devido à menor adaptabil idade, especialmente na auséncia do fungicida, demonstrada pela reduzida taxa de crescimento e capacidade de esporuíação em relação à linhagem sensĩvel. 
DENNIS (7987b) demonstraram a menor sobrevivência das linhagens resistentes a dicarboximidas, a ém de menor capacidade de dispersão, contribuindo para a menor adaptabilidade de tais linhagens. Entretanto, a habilidade de infectar morangos destacados era igual para as linhagens sensiveis e resis tentes.

Resultados semelhantes foram obtidos por HISADA. et alii (1981) no estudo da adaptabilidade de linhagens de B. cinerea resistentes a procymidone. A menor capacidade de esporulação, sobrevivencia e patogenicidade eram as características das 7 inhagens resistentes responsāveis pelo não sur gimento de probiemas com resistēncia em condiçoes de campo.

Conĩdios de linhagens de $B$. cinerea sensiveis e resistentes a dicarboximidas foram misturados $150: 50 ; 10$ : 90) por GULLINO \& GARIBALDI (1981) e a competitividade de ca da lin'nagem foi avaliada in vitro e in vivo (videiras e roseiras), determinando-se a cada geração a porcentagem de coni dios resistentes e sensiveis. Em ambos os casos a linhagem resistente reduziu sensivelmente a sua frequência, demonstran do a sua menor adaptabilidade.

BEEVER \& BRIEN (1983) observaram que as 1 inha gens de $B$. cinerea resistentes a dicarboximidas apresenta- 
vam alta sensibilidade à pressão osmōtica, comprovada pelo menor crescimento em meio de cultura com $\mathrm{NaCl}$, em relação à linhagem sensivel. Esta característica poderia contribuir pa ra uma menor adaptabilidade, representada por uma reduzida patogenicidade em frutos maduros, onde o acūmulo de açūcares solūveis contribuiria para uma alta pressão osmōtica. Resullados semethantes foram ob tidos por LEROUX \& CLERJEAU:1985), que observaram resistência cruzada negativamente correlacionada entre os dicarboximidas e alguns sais minerais ( $\mathrm{NaCl}$, $\mathrm{KCl}, \mathrm{CaCl} \mathrm{l}_{2}$ ), açücares (glicose, lactose, sacarose) e àlcoois (maritol e sorbitol).

os mecanismos pelos quais os fungos se tornam resistentes aos fungicidas, segundo BEEVER \& BYRDE(T982), são muitos, sendo que em alguns casos podem envolver o sitio de ação do produto, mas em outros podem não estar relacionados. Quanto aos dicarboximidas, pouco se sabe sobre o seu modo de ação e também do mecanismo de resistēncia.

Värios trabalhos provam que hā resistēncia cruzada positivamente correlacionada entre os dicarboximidas entre si (FRITZ et alii, 1977; CHASTAGNER \& VASSEY, 1979; PRESLY \& MAUDE, 1982; HARTILL et aizi, 1983; LEROUX \& CLERJEAU; 1985) e entre os dicarboximidas e o grupo dos hidrocabonetos aromáticos (FRITZ et alii, 1977; LEROUX et alii, 1977; 
GEORGOPOULOS et alii, 1979; PAPPAS et alii, 1979 ; PRESLY \& MAUDE, 1982; KATAN, 1982b; HARTILL et alii, 1983; LITTLEY \& RAHE, 1984).

Vărias características das 1 inhagens resisten tes a dicarboximidas têm sido examinadas, segundo BEEVER \& BYRDE (1982), na esperança de que elas possam revelar o meca nismo de resistência e os fatores que alteram sua adaptabili dade. Todavia, esses autores alegam que ha muito pouca infor mą̧ão para outras espëcies alēm de Botrytis cinerea, cuja in terpretação dos resultados è dificultada devido à sua grande variabilidade, como tambēm ocorre com $B$. squamosa (BERQUIST \& LORBEER, 1973). A ocorrēncia de heterocariose e a presença de vārios nücleos por conĩdio (MORGAN, 1971) fazem com que as caracteristicas apresentadas pela linhagem resistente pos sam ser um reflexo dessa variabilidade, mais do que uma consequēncia da presença de um gene particular de resistēncia. 
3. MATERIAL E METODOS

Os experimentos foram realizados nos laboratōrios do Departamento de Fitopatologia da Escola Superior de Agricultura "Luiz de Queiroz"/USP.

\section{1. Isolamento}

Folhas de cebola (Allium cepa L.) com sintoma de queima das pontas, de diferentes procedencias (Tabela 1), foram colocadas em cânara úmida (placa de Petri com dois dis cos de papel de filtro umedecidos com àgua destiiada) e submetidas a $20{ }^{\circ} \mathrm{C}$ e 1 uz fluorescente continua. A luminosidade foi fornecida por quatro lámpadas fluorescentes, luz do dia, de 40 watts, marca Philips, colocadas a uma altura de, apro-ximadamente, $30 \mathrm{~cm}$, em uma câmara de crescimento (Biotronette Mark III, Lab-Line Instruments). Apōs 24 horas de incubação apareceram conidióforos e conĩdios tīpicos do gênero Botrytis (BARNETT \& HUNTER, 1972) que, sendo facilmente visĩveis sob um microscópio estereoscópico, foram transferidos, com auxílio de uma agurha histológica, para placas de Petri contendo meio de cultura de cebolinha (forhas de Alzium fistulosum L. - 100g; āgar - 20g; āgua destilada - q.s.p. $1000 \mathrm{~m} 1$ ), com a finalidade de identificar os isolados de $B$. squamosa e obter culturas puras (GHINI, 1984). 


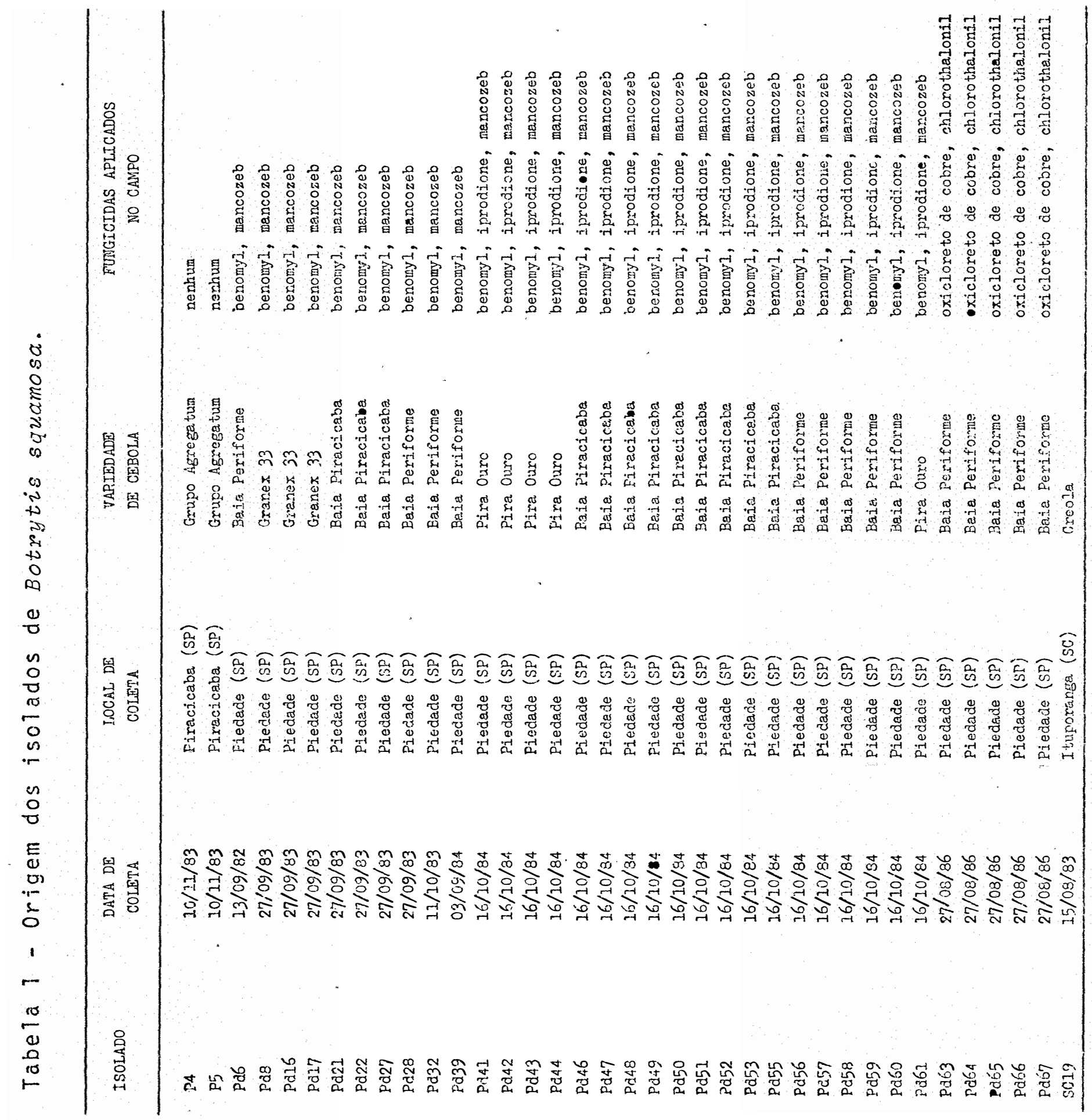




\subsection{Preservação do fungo}

Os isolados de Botrytis squamosa foram preser vados em tubos de ensaio contendo meio de curtura de BDA inclinado (batata - 200g; dextrose - 20g; ägar - 20g; āgua des tilada - q.s.p. $1000 \mathrm{~m}$ I), através de transferências sucessi vas, e em àgua, segundo o mëtodo de Casteliani, descrito por FIGUEIREDO (1967): os fungos são repicados, através de disco de meio de cultura contendo micério, para vidros de penicilina, com capacidade de $6 \mathrm{ml}$, contendo 4 a $5 \mathrm{ml}$ de água des.tilada esterilizada; em seguida, os vidros são tampados com rolhas de borracha e lacrados com tampas herméticas de alumi nio, com auxîlio de uma máquina cravadora especial. Segundo FIGUEIREDO \& PIMENTEL (1975), isolados de Botrytis tuitpae foram mantidos viāveis por esse método, por um periodo de pelo menos 8 anos.

\subsection{Produção de conîidios.}

Conídios foram produzidos em meio de cultura de cebolinha, contido em placas de Petri, sob condições de câmara de crescimento durante 10 dias, com temperatura de $24^{\circ} \mathrm{C}$ no periodo 1 uminoso e $15^{\circ} \mathrm{C}$ no período escuro, sendo 0 fotoperiodo de 14 horas. A luminosidade dessa câmara é confe rida por uma lámpada fluorescente, luz do dia, e duas lãmpa 
das próximas ao ultravioleta (NUV), de 40 watts, marca Philips, colocadas a uma altura de $30 \mathrm{~cm}$, aproximadamente. $0 \mathrm{~m} \underline{\underline{E}}$ todo adotado se baseia no trabalno de esporulação de $B$. squa mosa feito por BERGQUIST et alii (1972), con as modificações utijizadas por GHINI (1984).

\subsection{Frequēncia e grau de resistência}

A frequéncia e o grau de resistência a fungi. cidas dos isolados de Boirytis squamosa foram testados atravēs do método do fungicida incorporado ao meio de cuitura.

os isolados foran repicados: atraves de discos de meio de cultura contendo micélio (ciañietro de $0,7 \mathrm{~cm}$ ), para placas de Petri contendo BDA com concentrações de 0,1 , 10, 100 e 1000 ppm de benomyl (1-butiicarbamoil) - 2-benzi. midazol carbamato de metil o, produto comercial: Benlate 500) e iprodione $(3-(3,5-$ diclorofenil) - N - (1- metiletil) 2,4 - dioxo - 1- timidazolina carboximida; produto comercial: Rovral), em duas e trēs repetições, respectivamente.

As suspensões de benoniyl foram feitas em acetona $20 \%$ e as suspensões de iprodione em água destilada. 0 iprodione foi incorporado ao meio de cultura fundido e resfriado a, aproximadamente, $45^{\circ} \mathrm{C}$, sendo que o benomy foi adi 
cionado antes da autoclavagem.

As placas foram incubadas a $20^{\circ} \mathrm{C}$, no escuro, sendo a avaliação feita após dois dias, determinando-se o crescimento linear atravēs de medições de diāmetro mëdio das culturas, exceto para os isolados $P d 63$ ate $P d 67$, cuja resistência a benomyl foi avaliada com 6 dias de idade.

\subsection{Ob tenção dá linhagem res istente a benomy?}

Com a finalidade de obter, em condições de la boratório, uma 1 inhagem de B.squomosa resistente a benomyl e sensîvel a iprodione, suspensões de conĩdios do isolado P4 (sensivel a benomyl e iprodione) foram transferidas para pla cas de Petri contendo BDA com 0,500 e 1000 ppm de benomyl, em 5,11 e 33 repetições, respectivamente. A concentração das suspensões de conĩdios era de, aproximadamente, $10^{6}$ coni dios/ml, sendo transferido $l \mathrm{ml}$ por placa de Petri.

A seguir, as placas foram incubadas, durante 20 dias, em condições de cāmara de crescimento, com fotoperīodo de 14 horas, à temperatura de $240 \mathrm{C}$ no período luminoso e $15^{\circ} \mathrm{C}$ no período escuro, sendo a luminosidade fornecida por duas làmpadas próximas ao ultravioletá e uma fluorescente, 1 uz do dia, de 40 watts, marca Philips, colocadas a uma altu 
ra de $30 \mathrm{~cm}$, aproximadamente. A avaliação foi feita através da observação do crescimento de culturas de $B$. squamosa.

\subsection{Obtenção da 1 inhagem resistente a iprodione}

A obtenção da 7 inhagem resistente a iprodione foi realizada, em condições de laboratório, a parțir de uma linhagem sensĩvel a benomyl e iprodione. Para tanto, suspen sões de conĩdios do isolado P4, com concentração de $10^{5}$ conĩ. dios/ml, aproximadamente, foram transferidas para 30 placas de Petri (l ml/placa) contendo BDA com 500 ppm de iprodione e 3 placas sem o fungicida, para comprovar a viabilidade dos conídios.

A incubação foi realizada em condições de câmara ambiente com fotoperiodo de 12 horas, sendo a temperatu ra de $24{ }^{\circ} \mathrm{C}$ no período luminoso e $150 \mathrm{C}$ no perīodo escuro. A luminosidade foi fornecida por duas lämpadas próximas ao ul travioleta (NUV) e uma lämpada fluorescente, luz do dia, de 40 watts, colocadas a uma altura de $30 \mathrm{~cm}$, aproximadamente.

Após uma semana de incubação, foi observado o nūmero de linhagens resistentes a iprodione e seu crescimento micelial. A linhagem que apresentou maior vigor no cres cimento micelial no meio de cultura de BDA contendo 500 ppm de iprodione foi selecionada para utilização em experimentos 
posteriores.

\subsection{Ob tenção da linhagem duplo-resistente}

A linhagem de $B$. squamosa duplo - resistente, ou seja, resistente a benomyl e iprodione, foi obtida a partir de um isolado benomyl-resistente e iprodione - sensivel, em condições de laboratōrio.

Suspensões de conĩdios $\left(10^{3} \operatorname{conĩdios/mil)~do~}\right.$ isolado Pd44 (resistente a benomyl e sensĩvei a iprodione)foram tratadas com luz ultravioleta, fornecida por uma lâmpada germicida (Tungsram), $15 \mathrm{~W}$, colocada a uma altura de $40 \mathrm{~cm}$. 0 tempo de exposição à luz ultravioleta foi de 6 minutos que, segundo GRINDLE (1979), corresporide à DL9O (dose letal a $90 \%$ dos conîdios). A seguir, as suspensões de conídios, tratadas ou não, foram transferidas para placas de Petri (l ml/ placa) contendo meio de cultura de BDA com 10 ppm de iprodione, em 10 repetições, e para placas sem o fungicida, para comprovar a viabilidade dos conĩdios, em 2 repetições. A incubação foi realizada durante 20 dias, a uma temperatura de $24^{\circ} \mathrm{C}$ no período luminoso e $150 \mathrm{C}$ no perīodo escuro, sendo o fotoperĩodo de 14 horas e a luminosidade fornecida por duas làmpadas pró ximas ao ultravioleta (NUV) e uma fluorescente, luz do dia, de 40 watts, marca Philips. 
Após o perĩodo de incubação, as linhagens obtidas através de tratamento com 1 uz ultravioleta (IUV? e IUV2), juntamente com o isolado Pd44 e M5 (Pd44.77.7.20.5.10, obtido na quinta geração de transferēncia monospórica do isolado Pd44, ver 3.9.6.) foram transferidos para meio de cultura de BDA com gradiente de iprodione (0 a $100 \mathrm{ppm})$. Este meio de cultura foi preparado vertendo-se, inicialmente, BDA com 100 ppm de iprodione nas placas de Petri inclinadas e, depois de solidificado este meio, completando-se a placa na posição ho rizontal com BDA sem o fungicida. Assim, discos de meio de cultura contendo micélio $(0,7 \mathrm{~cm}$ de diāmetro) foram transferidos para tais placas nos bordos correspondentes a 0 ppm de iprodione, em 3 repetições e placas sem o fungicida, em 2 re petições. A incubação foi feita em condições de câmara de crescimento, com fotoperiodo de 14 horas, a $240^{\circ} \mathrm{C}$ no periodo luminoso e $150 \mathrm{C}$ no escuro, sendo a luminosidade fornecida por duas lâmpadas próximas ao ultravioleta e uma fluorescente,luz do dia, durante um mês.

Após o perīodo de incubação, discos $(0,7 \mathrm{~cm}$ de diāmetrol foram retirados dos bordos das placas de Petri correspondentes à concentração de $100 \mathrm{ppm}$ de iprodione e transferidos para piacas contendo meio de cultura de BDA com 1000 ppm de benomyl e 100 ppm de iprodione, em 5 repetições. A incubação foi realizada em condições de câmara de cresci- 
mento, com a mesma regulagem anterior, durante 10 dias. A se guir, para cada linhagem, foi selecionada a repetição que apresentava maior diāmetro de crescimento. Da placa selecionada foram retirados discos de $0,7 \mathrm{~cm}$ de diāmetro e transferidos para placas de Petri contendo BDA com gradiente de iprodione de 0 a 1000 ppm, em 5 repetições, sendo feita a in cubação nas mesmas condições anteriores. Após cultivo em meio com gradiente de iprodione, 0 isolado P. 44 passou a ser denominado Pd44G. Depois de um mês, foi testado o crescimento das linhagens em meio de cultura de BDA contendo 1000 ppm de benomyl e 500 ppm de iprodione.

Para tanto, discos $(0,7 \mathrm{~cm}$ de diâmetro) foram retirados dos bordos das placas de Petri correspondentes a 1000 ppm de iprodione e transferidos para placas contendo BDA com 1000 ppm de benomyl e 500 ppm de iprodione e placas sem os fungicidas, em 5 repetições. A incubação foi feita a $22^{\circ} \mathrm{C}$, no escuro, durante uma semana, quando foi feita a avaliação atravēs da medição do diàmetro médio das culturas.

A seleção do duplo-resistente foi feita levan do-se em consideração a linhagem que apresentou melhor desem penho quanto a crescimento micelial, além de vigor e esporulação, observados visualmente. 


\subsection{Sensibilidade colateral}

Dois ensaios foram realizados para avaliar a sensibilidade colateral das linhagens de $B$. squamosa, atraves do método do fungicida incorporado ao meio de cultura. No primeiro foram utilizados os seguintes isolados obtidos em produções comerciais de cebola: P4, Pd17, Pd32, Pd39,Pd51, $P d 53, P d 56, P d 60$ e $P d 61$ para mancozeb (etilenobisditiocarbamato de manganês com ion zinco; produto comercial: Dithane M! 45) e os isolados P4, Pd8, Pdl7, Pd27, Pd32, Pd44, Pd58 e SC19 para captafol (N- (1, 1,2, 2- tetracloroetiltio) - 4- ciclo hexeno - 1,2- dicarboximida; produto comercial: Difolatan $480)$, captan (N- (triclorometiltio) - 4- ciclohexeno - 1,2dicarboximida; produto comercial Orthocide 750), dicloran (1,2- dicloro - 4-nitroanilina; produto comercial: Botran 75PM), procymidone $(n,(3,5-$ diclorofenil) - 1,2- dimetil ciclo propano - 1,2- dicarboximida; produto comercial: Sumilex) e propiconazol (1- $2-(2,4-$ diclorofenil) - 4-propil - 1,3dioxolan - 2- IL - metil) - $1 H$ - 1,2, 4 triazol; produto comercial: Tilt).

As suspensões estuque de fungicidas; para 0 primeiro ensaio, foram feitas em acetona $20 \%$ para benomy 1 , em àlcool etîlico $20 \%$ para captan, captafol, dicloran, mancozeb, propiconazol e procymidone e em água destilada para iprodione. 
De cada suspensão es toque foi feita diluição em sērie, tomada uma alíquota de $1 \mathrm{ml}$ e transferida para o meio de cultu ra de BDA fundido e resfriado a, aproximadamente, 450C (exce to benomyl, que foi acrescentado antes da autoclavagem), de tal forma a se obter concentrações de 1, 10, 100 e 1000 ppm. De forma anāloga foi preparada a testemunha sem a adição de fungicida.

No segundo erisaio foram testadas as linhagens: P4 (sensível a benomyl e ip̣rodione); Pd27 e Pdó7 (resistentes a benomyl e sensiveis a iprodione); P4BSIR (obtida em condições de laboratōrio, sensível a benomyl e resistente a iprodione) e IUVI (obtida em condições de laboratório, resís tente a benomyl e iprodione). Os fungicidas utilizados foram: benomyl (produto comercial: Benlate 500), iprodione (pro dução comercial: Rovral), procymidone (produto comercial, Dicyclidine 50\%), captan (produto comercial: Captan 750), captafol (produto comersial: Orthodifolatan 70), dicioran (pro duto comercial: Botran 75 PM), mancozeb (produto comercial: Dithane M45) e propiconazol (produto comercial: Tilt). Para o preparo dos meios de cultura com fungicida, foi feita uma suspensão estoque dos produtos em ālcool etīlico $20 \%$ (exceto iprodione que foi suspenso em água destilada), sendo tomada uma alíquota constante de $l \mathrm{ml}$ de cada solução e transferida para $300 \mathrm{ml}$ de BDA fundente $\left(45^{\circ} \mathrm{C}\right.$, aproximadamente), de tal 
forma a se obter a concentração de 100 ppm. Simultaneamente, foi preparada a testemunha sem a adição de fungicida.

Nos dois ensaios as 1 inhagens foram transferi das para as placas de Petri através de discos de meio de cul. tura contendo micēlio (diāmetro de $0,7 \mathrm{~cm}$ ), em 3 repetições, e incubadas no escuro a $20^{\circ} \mathrm{C}$, durante dois e quatro dias para o primeiro e o segundo ensaio, respectivamente. A avaliação foi feita atravēs da medição do diāmetro médio das culturas.

\subsection{Adaptabilidade}

3.9.1. Crescimento micelial

As 1 inhagens P4 (sensível a:benomyl e iprodione), Pd27 e Pd67 (resistentes a benomyl e sensíveis a iprodione), P4BSIR (sensível a benomyl e resistente a iprodione) e IUVI (duplo-resistente) foram tes tadas quanto ao crescimento 1 inear em meio de cultura de BDA.

Discos de meio de cultura $(0,7 \mathrm{~cm}$ de diāmetro) contendo micēlio das linhagens foram transferidos para placas de Petri contendo BDA, em 4 repetições, e incubados a $20^{\circ} \mathrm{C}$, no escuro. A avaliação foi feita atravēs da medição 
diāria do diāmetro médio das culturas.

\subsubsection{Esporulação}

As linhagens P4 (sensivel a benomyl e iprodione), Rd27 e Pd67 (resistentes a benomyl e sensiveis a iprodione), P4BSIR (sensivel a benomyl e resistente a iprodione) e IUVI (duplo-resistente) foram testadas quanto à esporulação em meio de curtura.

Discos de meio de cultura (diāmetro de $0,7 \mathrm{~cm}$ ) contendo micēilo das linhagens foram transferidos para placas de Petri contendo meio de cultura de cebolinha, em 4 repetições, e incubados em câmara de crescimento com temperatú ra de $24^{\circ} \mathrm{C}$ no período luminoso e $15^{\circ} \mathrm{C}$ no perīodo escuro, sen do o fotoperíodo de 14 horas. A luminosidade foi conferida por uma lâmpada fluorescente, luz do dia, e duas lâmpadas prö ximas ao ultravioleta (NUV), de 40 watts, marca Philips, colocadas a uma altura de $30 \mathrm{~cm}$, aproximadamente.

Após uma semana de incubação, foi feita uma suspensão de conĩdios em àgua destilada, filtrada em gaze e a avaliação foi realizada atravēs da contagem, em hemocitōmetro, dos conídios produzidos por placa de Petri. 


\subsubsection{Patogenicidade}

A patogenicidade das 1 inhagens P4 (sensivel a benomyl e iprodione), $P d 27$ e $P d 67$ (resistente a benomyl e sen sível a iprodione), P4BSIR (sensível a benomyl e resistente a iprodione) e IUVI (duplo-resistente) foi testada atravēs da inoculação de suspensão de conĩdios em plântulas de cebola e inoculação de micēlio em discos de escama de buibo.

No primeiro teste, suspensões de conídios $\left(10^{4}\right.$ conidios/mi) foram inoculadas com puiverizador De Vilbiss em pläntulas de cebola da cultivar Baia Periforme. Cadá Iinhagem foi inoculada em dois vasos ( $5 \mathrm{ml}$ de suspensão de conídios/vasol, sendo que cada vaso, com capacidade de $300 \mathrm{ml}$, continha, aproximadamente, 25 pläntulas com $45^{\circ}$ dias de idade. Como tes temunha, dois vasos foram pulverizados com ägua destillada. Após a inoculação, os vasos foram mántidos a $200 \mathrm{C}$, sob luz fluorescente contínua, permanecendo. em câmara úmida nas primeiras 24 horas. Quatro dias apōs a inoculação, a avaliação foi feita atravēs da contagem de folhas apresen tando sintoma de queima da ponta em cada vaso.

No segundo teste, discos de meio de cultura $(0,7 \mathrm{~cm}$ de diānetro) contendo micēlio das linhagens foram inoculados em discos $(1,8 \mathrm{~cm}$ de diāmetro) de escamas internas 
de bulbo de cebola Baia Periforme. Cada linhagem foi inocula da em quatro discos de escama contidos em placas de Petri, em quatro repetições, totalizando 16 discos por isolado. A inoculação foi feita ferindo-se o disco do lado externo da esca ma com auxilio de uma agulha histológica e, a seguir, colocando-se sobre o ferimento, um disco de meio de cultura contendo micélio do patōgeno, de modo que o micēlio permaneces se em contato direto com o ferimento. Como testemunha foram utilizados discos de escama que receberam ferimento e um disco de meio de cultura sem o patōgeno. A incubação foi realizada em placas de Petri de plástico contendo dois discos de papel de filtro umedecidos com ägua destilada, colocadas sob Tuz fluorescente contīnua e $20^{\circ} \mathrm{C}$. A avaliação foi feita 3 e 6 dias apōs a inoculação, atravēs da observação dos discos que apresentavam sintoma de podridão e crescimento mi.celial.

\subsubsection{Competição in vitro}

A competição in vitro entre as linhagens sen siveis e resistentes a benomy 1 foi testada atravēs de transferēncia sucessivas de suspensões de conîdios calibradas, inicialmente, com $50 \%$ dos conidios da linhagem resistente e $50 \%$ da sensîvel.

Para tanto, foram preparadas suspensões de co 
nídios da linhagem P4 (sensĩvel a benomyl), Pd27 e Pd67 (resistentes a benomy 1 ), com concențração de $4 \cdot 10^{4}$ conĩdios/ml. Uma gota (volume de $1 / 80 \mathrm{ml}$ ) da suspensão de conĩdios da linhagem sensível a benomyl foi colocada no centro da placa de Petri, contendo meio de cultura de cebolinha, e a seguir foi colocada uma gota da suspensão de conĩdios da linhagem resistente ( $P d 27$ ou $P d 67)$, em 5 repetições. Para testar a viabilidade dos conĩdios de cada isolado, suspensões de conĩdios de cada linhagem foram transferidas separadamente para placas de Petri, em 3 repetições.

A incubação foi realizada em condições de câma ra de crescimento, com fotoperĩodo de 14 horas, sendo a tempe ratura de $24^{\circ} \mathrm{C}$ no período luminoso e $15^{\circ} \mathrm{C}$ no período escuro. A luminosidade foi fornecida por duas lāmpadas prōximas ao u travioleta (NUV) e uma fluorescente, luz do dia, de 40 watts, marca Philips, culocadas a uma altura de $30 \mathrm{~cm}$, aproximadamen te,

Após uma semana de incubação, foram feitas sus pensões dos conĩdios em āgua destilada, para cada placa de Petri, sendo transferidas duas gotas para novo meio de cultura de cebolinha. Dessa forma as suspensões de conídios foram transferidas sucessivamente in vitro até que uma das linhagens desaparecesse. 
Para avaliar a proporção de conídios resisten tes e sensíveis a benomy 1, a cada transferência eram feitas repicagens monospōricas e a seguir era testado, de forma qua litativa, o crescimento dess as linhagens em meio de BDA contendo $500 \mathrm{ppm}$ de benomy 1. A repicagem monospōrica foi realizada a partir de $1 \mathrm{ml}$ da suspensão de conídios de cada trata mento, colocado em placas de Petri contendo āgar - āgua e in cubado por 18 horas no escuro para permitir a germinação dos conídios. Apōs a germinação, os conĩdios eram identificados sob microscópio ótico e transferidos para meio de cultura de cebolinha. Com dois dias de idade, discos de meio de cultura $(0,7 \mathrm{~cm}$ de diàmetro) contendo micélio das linhagens monospóricas eram transferidos para placas de Petri contendo BDA com $500 \mathrm{ppm}$ de benomyl e incubados a $20^{\circ} \mathrm{C}$ no escuro. Após dois dias de incubação, era determinado o nümero de linhagens que cresciam ou não no meio de cultura com o fungicida, correspon dendo à proporção de conĩdios resistentes e sensíveis a beno my 1 , respectivamente.

\subsubsection{Competição in vivo}

A competição in vivo entre as linhagens sensî́ veis e resistentes a benomyl foi avaliada através de transfe rência sucessiva de inóculo calibrado, inicialmente, com igual concentração de conĩdios de cada linhagem. 
Dois experimentos foram efetuados com tal finalidade. No primeiro foram testadas as linhagens resistentes a benomy 1: Pd27, Pd64, Pd65 e $P d 67$, ao passo que no segundo testou-se somente $P d 27$ e $P d 67$. Em ambos, a limagem sen sível a benomyl usada paru a comparação foi P4.

Sementes de cebola da cultivar Baia Periforme foram semeadas em vasos plásticos, com capacidade de $300 \mathrm{ml}$, contendo solo esterelizado. Com um mês de idade, as plāntulas foram inoculadas, com auxílio de um pulverizador De Vilbiss, com suspensões de conídios ( $4.10^{4}$ conĩdios/ml), sendo $50 \%$ dos conídios da linhagem sensível e $50 \%$ da resistente a benomyl. Antes da inoculação, foram retiradas as folhas mais velhas das plāntulas, permanecendo somente folhas verdes.

No primeiro experimento foram utilizadas quatro repetições por tratamento, sendo que cada repetição cons tituiu-se por um vaso com, aproximadamente, 5 plàntulas inocu ladas com $1 \mathrm{ml}$ de suspensão de conĩdios. No segundo experimen to, foram utilizadas trēs repetições por tratamento, sendo que cada repetição cons ti.tuiu-se por um vaso com, aproximadamente, 25 plāntulas inoculadas com $3 \mathrm{ml}$ de suspensão de co nídios. 
das de forma semelhante aos demais tratamentos, com āgua des til ada. Para confirmar a viabilidade dos conídios, as linha gens foram também inoculadas separadamente.

A incubação ocorreu em condições de cāmara de crescimento, com fotoperíodo de 14 horas, sendo a temperatura no período 1 uminoso de $250 \mathrm{C}$ e no período escuro de $150 \mathrm{C}$. A luminosidade foi fornecidada por duas lâmpadas próximas ao ultravioleta e uma fluorescente, luz!do dia, de 40 watts, mar ca Philips, colocadas a uma altura de $30 \mathrm{~cm}$,aproximadamente. Durante as primeiras 24 horas após a inoculação, os vasos permaneceram em câmara ümida.

Apōs uma semana de incubação, as folhas das plântulas foram retiradas e colocadas sob condições que favo recem a produção de conĩdios, semelhantes às utilizadas para isolamento (ver 3.1.), durante dois dias. Após esse período foram feitas suspensões de conidios que foram inoculadas em plântulas cie cesola, repetindo-se o método até a eliminação de uma das linhagens testadas na mistura.

Para avaliar a proporção de conídios resisten tes e sensíveis a benomy 1, a cada transferēncia de inóculo eram feitas repicagens monospōricas e testadas, qualitativamente, quanto ao crescimento em meio de cultura de BDA contendo 500 ppm de benomyl, como foi feito para avaljar a com- 
petição in vitro (ver. 3.9.4):

3.9.6. Estabilidade da resistência a benomy

A estabilidade da resistēncia a benomyl foi avaliada atravēs de sucessivas transferēncias monospóricas in vitro do isolado Pd44.

Suspensões de conĩdios do isolado Pd44 foram transferidas para placas de Petri contendo meio de cultura de BDA e incubadas por 18 horas no escuro, a $200 \mathrm{C}$. Após esse período, os conídios germinados eram identificados sob microscópio ótico, transferidos isoladamente para placas de Pe tri contendo meio de cultura de cebolinha e incubados em con dições que favorecem a produção de conĩdios (ver 3.3).

As transferēncias monospōricas foram realizadas durante cinco gerações, sendo que do isolado original Pd44 foram obtidas 18 linhagens monospōricas (Pd44-1 a té Pd44-18); a segunda geração monospōrica (Pd44-17-1 até Pd44-17-13) foi obtida a partir de $P d 44-17$; a terceira geração (Pd44-17-7-1 atē Pd44-17-7-21) foi obtida a partir de Pd44-17-7; a quarta geração (Pd44-17-7-20-1 a tē Pd44-17-7-20-12) a partir de Pd44-17-7-20 e a quinta geração(Pd44-17-7-20-5-1 até Pd44-17-7-20-5-15) a partir de Pd44-17-7-20-5. 
Cada geração de monospóricos foi testada quan to a resistência a benomyl, atravēs do método do fungicida incorporado ao meio de cultura. Discos de meio de cultura $(0,7$ cm de diāmetrol contendo micēlio foram transferidos para plá cas de Petri contendo BDA com 1000 ppm de benomyl, em 3 repetições. As placas foram incubadas no escuro a $20^{\circ} \mathrm{C}$, sendo a avaliação feita 48 horas apōs, atrayēs da medição do diāme tro mēdio das culturas.

3.9.7. Es tabilidade da resistência a benomyl e iprodione

A estabilidade da resistēncia a benomy l e iprodione foi avaliada atravēs de sucessivas transferēncias monospōricas in vitro da linhagem IUVI.

Suspensões de conídios de IUVl foram transferidas para placas de Petri contendo āgar - āgua e incubadas no escuro, durante 18 horas, a $20^{\circ} \mathrm{C}$. A seguir, os conídios germinados foram identificados sob microscópio ótico e trans feridos para placas de Petri contendo meio de cultura de cebolinha, que foram incubadas em condições que permitem a pro dução de conídios (ver 3.3.).

Cinco gerações de transferēncias monospōricas foram obtidas, sendo que de IUVI foram obtidas 20 linhagens 
monospōricas (IUVI-l a tē IUVI-20); a segunda geração monospō rica (IUVI-8-1 atē IUV1-8-22) foi obtida a partir de IUV1-8; a terceira geração (IUV1-8-17-1 atē IUV1-8-17-15), a partir de IUVI-3-17; a quarta geração (IUVI-8-17-10-1 a té IUVI-8-17-10-20), a partir de IUV1-8-17-10 e a quinta geração (IUVI-8-17-10-3-1 a té IUVI-8-17-10-3-20), a partir de IUV1-8-17-10-3.

Para cada geração obtida, as linhagens monospōricas foram testadas quanto a resistência a benomy 1 e iprodione através do método do fungicida incorporado ao meio da cultura. Discos de meio de cultura $(0,7 \mathrm{~cm}$ de diāmetro) contendo micēlio das linhagens foram transferidos para placas de Petri contendo meio de cultura de BDA, BDA com 1000 ppm de benomy 1, BDA com 500 ppm de iprodione e BDA com 500 ppm de iprodione e 1000 ppm de benomyl, em 3 repetições. As placas foram incubadas no escuro, a $200 \mathrm{C}$, sendo a avaliação realizada apōs 3 dias, atravēs da medição do diāmetro médio das culturas.

\subsection{Anas tomose de hifas}

A formação de anastomose entre as hifas dos isolados de Botrytis squamosa foi observada in vitro, sob microscópio ótico. Para tanto, as linhagens foram dispostas duas a duas, atravēs da colocação de discos de meio de curtú 
ra $(0,7 \mathrm{~cm}$ de diâmetro) contendo micēitio, nas extremidades de fitas de membrana de diālise $(0,8 \times 4,0 \mathrm{~cm})$, previamente es terelizadas e mergulhadas em meio de cultura de cebolinha fundente. Foram colocadas, em forma de "Y", 3 fitas de membrana de diālise por placa de Petri contendo āgar - āgua, em 8 placas.

As placas foram incubadas em condições de luminosidade contínua (làmpadas fluorescentes, luz do dia, de 40 watts, marca Philips, colocadas a uma altura de $30 \mathrm{~cm}$,apro ximadamente), a $20^{\circ} \mathrm{C}$, durante 2 dias.

Apōs o perīodo de incubação, as placas foram examinadas, sob microscópio ótico, observando-se a presença ou não de anastomose de hifas.

3.11. Coloração de nūcleos de conĩdios

Para a determinação do nūmero de nūc?eos por conĩdio, foi utilizado o método de coloração de nūcleos utilizado por BARROS (1977).

Os conidios foram, inicialmente, fixados com solução de albumina a $5 \%$ em lâminas para microscópio. Apōs a secagem, foram fixados com sol ução de etanol, ácido acēti- 
co e ācido lático, na proporção $6: 1: 1$, durante 20 minutos. A seguir, foram feitas lavagens sucessivas em soluções alcoólicas a $95 \%, 70 \%, 50 \%$ e āgua destilada, durante 5 minutos ca da uma. Seguiu-se hidrölise em HCl $1 \mathrm{~N}$ por 5 minutos, em tem peratura ambiente, e por 6 minutos a $60-63^{\circ} \mathrm{C}$. Após a hidró lise, foram feitas cinco lavagens em āgua destilada, durante 7 minutos cada uma, e uma lavagem em tampão fosfato pH 7,2 $\left(\mathrm{NaHPO}_{4} \cdot \mathrm{7H}_{2} \mathrm{O}\right.$ e $\mathrm{KH}_{2} \mathrm{PO}_{4}$, na proporção $\left.7: 3\right)$, durante 20 minutos.

A coloração foi feita com solução de giemsa, durante 35 minutos. A giemsa foi preparada diluindo-se a solução es toque de giemsa em tampão fosfato pH 7,2, na proporção em volume 7:3, sendo a solução estoque composta de 250 ml de metanol, $250 \mathrm{ml}$ de glicerina e $28 \mathrm{~g}$ de giemsa.

Os isolados utilizados foram $P_{4}$ (sensivel a benomy 1) e Pd27 (resistente a benomyl), sendo feitas duas lâa minas por isolado e contados os nūcleos de 10 conĩdios por lâmina. 


\section{RESULTADOS}

\subsection{Frequência e grau de resistência}

A partir do crescimento micelial em meio de cultura contendo diferentes concentrações de benomyl, os iso lados de $B$. squamosa podem ser classificados quanto a sensibilidade ao fungicida (tabelas 2 e 3 ). Os isolados $\mathrm{P}_{4}$ e P.5 apresentaram-se sensiveis ao produto, sendo o seu crescimento inibido pela concentração de 1 ppm. Os demais isolados cresceram em todas as concentrações testadas de benomyl. Entretanto,houve uma redução no crescimento micelial com o aumento da concentração de benomyl.

Para os diāmetros médios de crescimento dos isolados resistentes a benomy 1 , apresentados na tabela 2, foi realizada uma regressão linear:

$$
y=1,09175-0,247375 x
$$

$$
\begin{aligned}
\text { Sendo: } y & =\text { diāmetro da cultura }(\mathrm{cm}) \\
x & =\text { logarîtmo da concentração de benomyl }(\mathrm{ppm}) \\
\text { teste } F & =171,08
\end{aligned}
$$


Dessa forma foi obtido o ED50 (concentração do fungicida capaz de inibir $50 \%$ do crescimento do isolado) de 246 ppm de benomyl.

os isolados foram considerados sensiveis a iprodione vis to que apresentaram pouco ou nenhum crescimento micelial em meio de cultura contendo 10 ppm do fungicida,sen do o crescimento totalmente inibido com 100 e 1000 ppm (tabe 1 a 4 ).

4.2. Obtenção da linhagem resistente a benomy?

Todos os conidios da linhagem P4 (sensivel a benomyl e iprodione), transferidos para meio de cultura, con tendo benomyl, foram inibidos pelo fungicida. Somente houve crescimento do fungo em meio de cultura sem o produto. Dessa forma não foi obtida uma linhagem resistente a benomyl, em condịções de laboratōrio. 


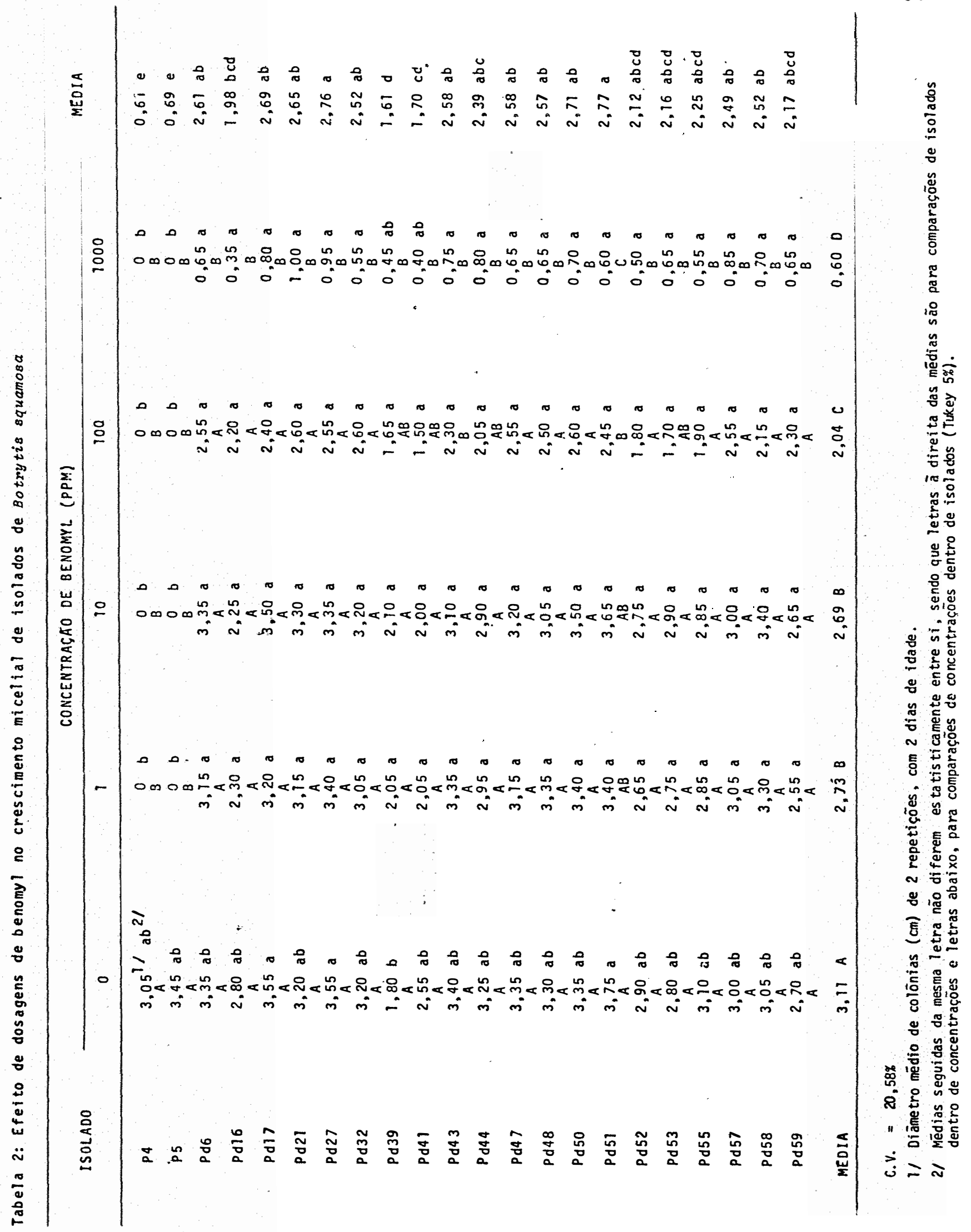


Tabela 3: Efeito de dosagens de benomyl no crescimento micelial de isolados de Botrytis squamosa.

\begin{tabular}{|c|c|c|c|c|c|c|}
\hline \multirow{2}{*}{ ISOLADO } & \multicolumn{5}{|c|}{ CONCENTRAÇÃO DE BENOMYL (PPM) } & \multirow{2}{*}{ MEDIA } \\
\hline & 0 & 1 & 10 & 100 & 1000 & \\
\hline Pd63 & $7,30^{1 /}$ & 7,88 & 6,30 & 2,63 & 0,80 & 6,03 \\
\hline Pd64 & 7,88 & 7,35 & 6,58 & 3,80 & 1,00 & 5,32 \\
\hline Pd65 & 8,30 & 7,55 & 7,25 & 4,20 & 0,70 & 5,60 \\
\hline Pd66 & 8,30 & 8,05 & 7,88 & 4,23 & 1,25 & 5,94 \\
\hline Pd67 & 8,30 & 8,30 & 8,30 & 3,83 & 0,85 & 5,92 \\
\hline MEDIA & 8,02 & 7,83 & 7,26 & 3,74 & 0,92 & \\
\hline
\end{tabular}

1/ Diāmetro médio de colōnias $(\mathrm{cm})$ de 2 repetições, com 6 dias de idade. 
Tabela 4: Efeito de dosagens de iprodione no crescimento micelial de isolados de Botrytis equamosa

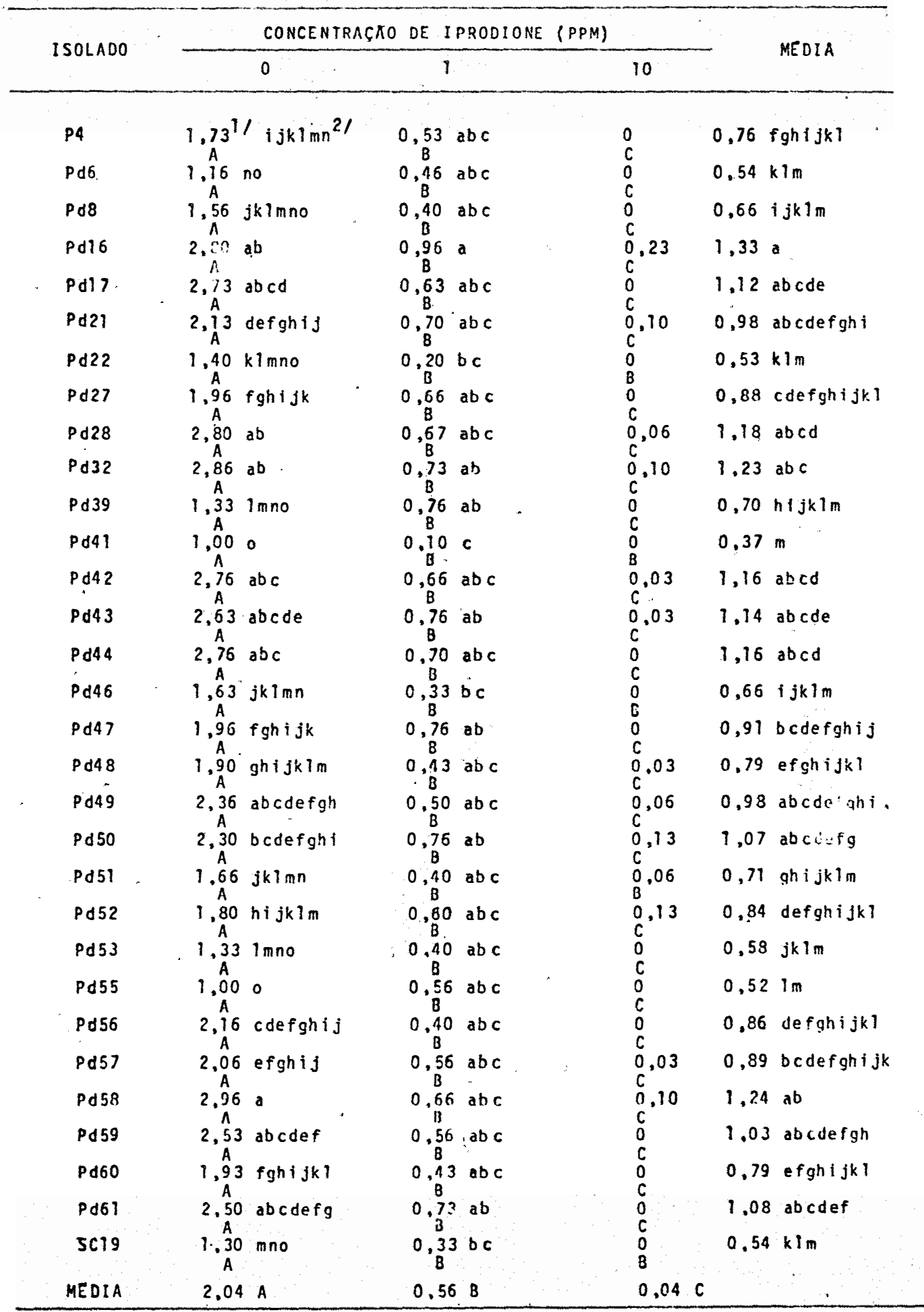

C.V. $=15,88 \%$

$1 /$ Diàmetro mëdio de colōnias $(\mathrm{cm})$ de 3 repetiçōes, com 2 dias de ldade.

21 Mēdias seguidas da mesma letra não dif erem estatisticamente entre si. s.endo que letras a direita das médias säo para comparacöes de isolados dentro de concentracoes e letras abolxo. para comparaçoes de concentraços dentro de isolados (rukey 5\%). 
4.3. Ob tenção da Tinhagem resistente a iprodione

Da transferência de suspensões de conĩdios do isolado P4 (sensiyel a benomyl e iprodione) para meio de cul tura contendo iprodione, foram obtidas cinco linhagens que foram consideradas resistentes a iprodione. Através de avaliação visual foi selecionada a linhagem apresentando crescimento mais vigoroso em meio de cultura contendo o fungicida e denominada P4BSIR.

\subsection{Ob tenção da 1 inhagem duplo-res is tente}

As quatro linhagens foram capazes de crescer em meio de cultura contendo 1000 ppm de benomyl e 500 ppm de iprodione (tabela 5), apōs transferēncia sucessivas em meio com gradiente de fungicida. Entretanto, a linhagem IUVl foi selecionada para participar dos experimentos seguintes pois, alēm de crescer em presença dos dois fungicidas, apresentou maior vigor e capacidade de esporular, avaliados visualmente. 
Tabela 5 - Efeito de benomy (1000 ppm) e iprodione(500 ppm) no crescimento micelial de linhagens duplo-res istentes obtidas a partir do isolado Pd44 de Botrytis squomosa.

LINHAGEM

DIÁMETRO DA COLONIA (CM) $1 /$

BDA

BDA COM BENOMYL E IPRODIONE

$P d 44 G^{21}$

7,81

1,59

$\mathrm{M5}^{3 /}$

8,30

1,15

IUVT $^{4 /}$

6,23

1,80

IUV $2^{4 /}$

6,35

1,85

1/ Mēdia de 5 rapetições, com 1 semana de idade.

2) Pd44 cultivado em meio de cultura com gradiente de iprodione.

3/ Pd44 apōs 5 gerações de transferēncias monospōricas.

.. 4/ Pd44 tratado com luz ultravioleta. 


\subsection{Sensibilidade colateral}

No primeiro ensaio, onde foram testados diferentes fungicidas em diversas concentrações, os isolados de B. squamosa, obtidos em condições de campo, apresentaram crescimento micelial em meios de cultura contendo somente baixas concentrações de captan, dicloran, procymidone e propiconazol (tabelas 7, 8, 10 e 11 , respectivamente), sendo portanto con siderados sensĩveis a esses fungicidas. Para captafol e mancozeb, alguns isolados foram capazes de crescer em todas as concentrações testadas (tabelas 6 e 9). A partir desses resultados foi calculada a faixa de concentração de fungicidas que contēm O ED50 (dose do fungicida suficiente para inj bir $50 \%$ do crescimento micelial) para cada isolado testado (tabela-12).

No segundo ensaio, as linhagens sensiveis a benomyi (P4 e P4BSIR) e as sensĩveis a iprodione (P4, Pd27 e Pd67) não cresceram em meio de cultura contendo esses fungicidas na concentração tes tada $(100 \mathrm{ppm})$, ao passo que as resistentes cresceram, como podem ser observados, de forma qualitativa, os resultados da tabela 13. Houve resistência cruzada entre iprodione, procymidone e dicloran. Nenhuma linhagem cresceu em meio de cultura contendo propiconazol. 


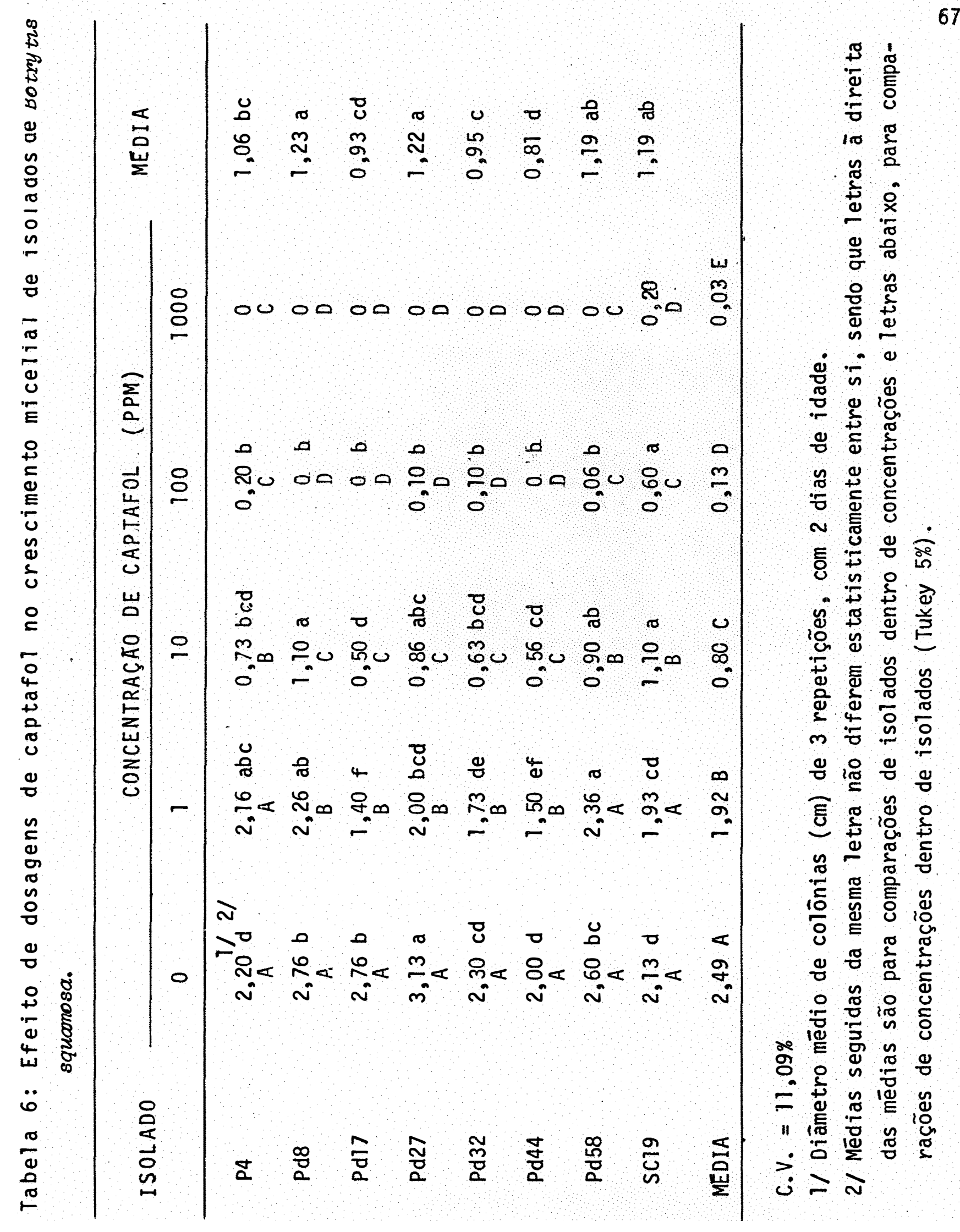


Tabela 7: Efeito de dosagens de captan no crescimento micelial de isolados de Botrytis squamosa.

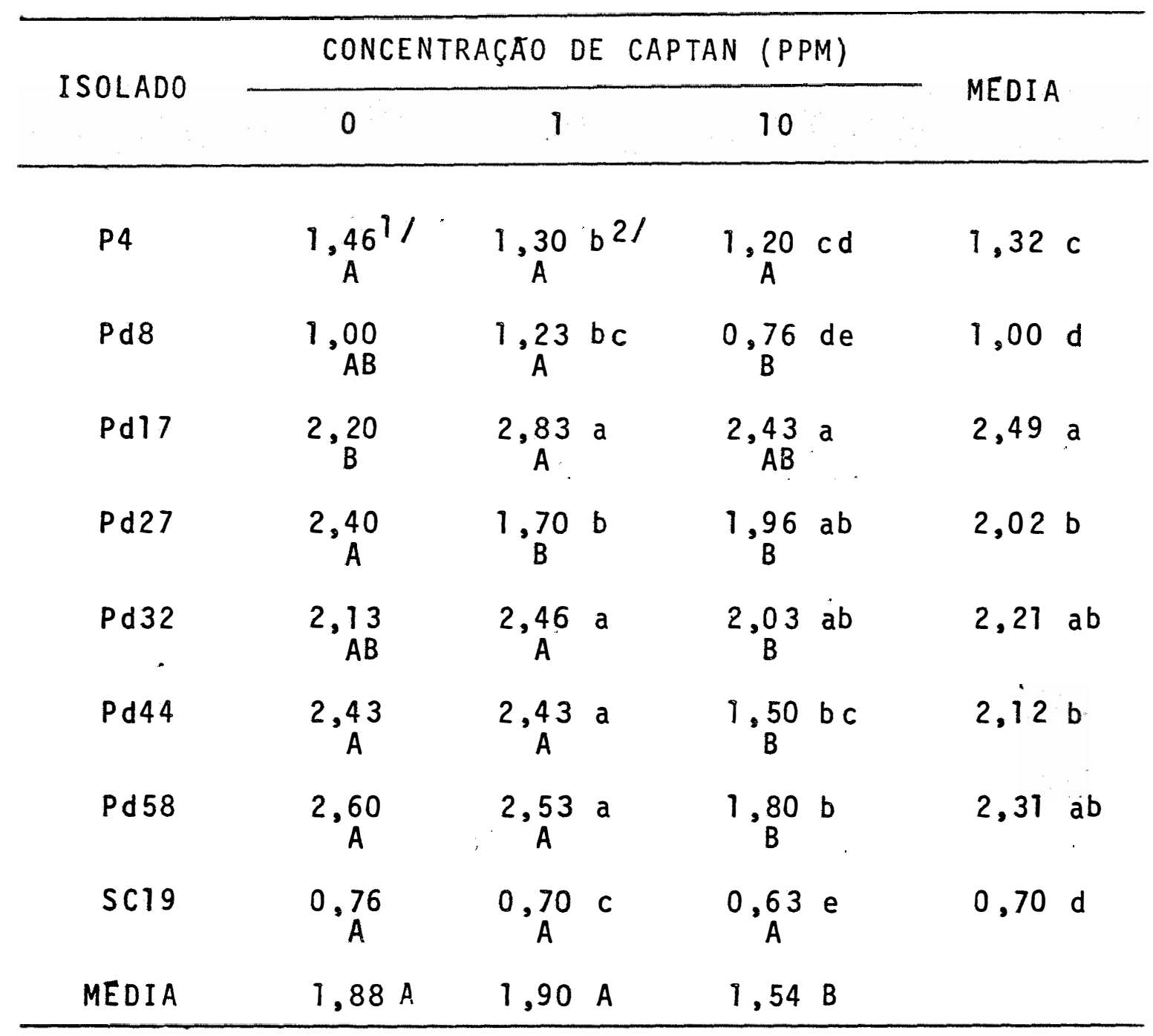

C.V. $=11,67 \%$

1/ Diâmetro médio de colónias $(\mathrm{cm})$ de 3 repetições, com 2 dias de idade.

2/ Médias seguidas da mesma letra não diferem estatisticamen te entre si sendo que letras à direita das mẽdias são pă ra comparações de isolados dentro de concentrações e letras abaixo, para comparações de concentrações dentro de isolados (Tukey $5 \%$ ). 
Tabela 8: Efeito de dosagens de dicloran no crescimento mice lial de isolados de Botrytis squamosa.

\begin{tabular}{|c|c|c|c|c|}
\hline \multirow{2}{*}{ ISOLADO } & \multicolumn{3}{|c|}{ CONCENTRAÇAOO DE DICLORAN (PPM) } & \multirow{2}{*}{ MEDIA } \\
\hline & 0 & 1 & 10 & \\
\hline P4 & $2,10^{1 /} c^{2 /}$ & $\begin{array}{c}1,36 \\
B\end{array}$ & $\underset{C}{0,20}$ & $1,22 \mathrm{~b}$ \\
\hline Pd8 & $\begin{array}{c}3,20 \\
A\end{array} a$ & $\underset{\mathrm{e}}{1,30} \mathrm{ab}$ & $\begin{array}{c}0,23 \\
C\end{array}$ & 1,58 a \\
\hline Pd17 & $\underset{A}{2,66 b}$ & $\underset{B}{1,13} a b$ & $\begin{array}{l}0 \\
C\end{array}$ & $1,27 \mathrm{~b}$ \\
\hline $\mathrm{Pd} 27$ & $\begin{array}{c}2,86 \\
A\end{array}$ & $\underset{B}{1,33} a b$ & $\begin{array}{l}0 \\
c\end{array}$ & $1,40 \mathrm{ab}$ \\
\hline Pd32 & $\underset{A}{3,20} a$ & $\underset{B}{1,40}$ a & $\begin{array}{c}0,16 \\
C\end{array}$ & $1,59 a$ \\
\hline $\mathrm{Pd} 44$ & $\begin{array}{c}1,90 \mathrm{c} \\
\mathrm{A}\end{array}$ & $\underset{B}{0,90 b}$ & $\begin{array}{l}0 \\
C\end{array}$ & $0,93 \mathrm{c}$ \\
\hline Pd58 & $\underset{A}{2,76} a b$ & $\underset{B}{1,53} a$ & $\begin{array}{c}0,03 \\
C\end{array}$ & $1,44 a b$ \\
\hline SCl9 & $\begin{array}{c}2,73 b \\
A\end{array}$ & $\underset{B}{1,26} a b$ & $\begin{array}{c}0,06 \\
C\end{array}$ & $1,36 a b$ \\
\hline Mēdia & $2,68 \mathrm{~A}$ & $1,28 \mathrm{~B}$ & $0,09 \mathrm{C}$ & \\
\hline
\end{tabular}

C.V. $=13,31 \%$

$1 /$ Diàmetro médio de colōnias $(\mathrm{cm})$ de 3 repetições, com 2 dias de idade.

2/ Médias seguidas da mesma letra não diferem estatisticamente entre si, sendo que letras à direita são para com parações de isoliados dentro de concentrações e letras abaī xo, para comparações de concentrações dentro de isolados (Tukey 5\%). 


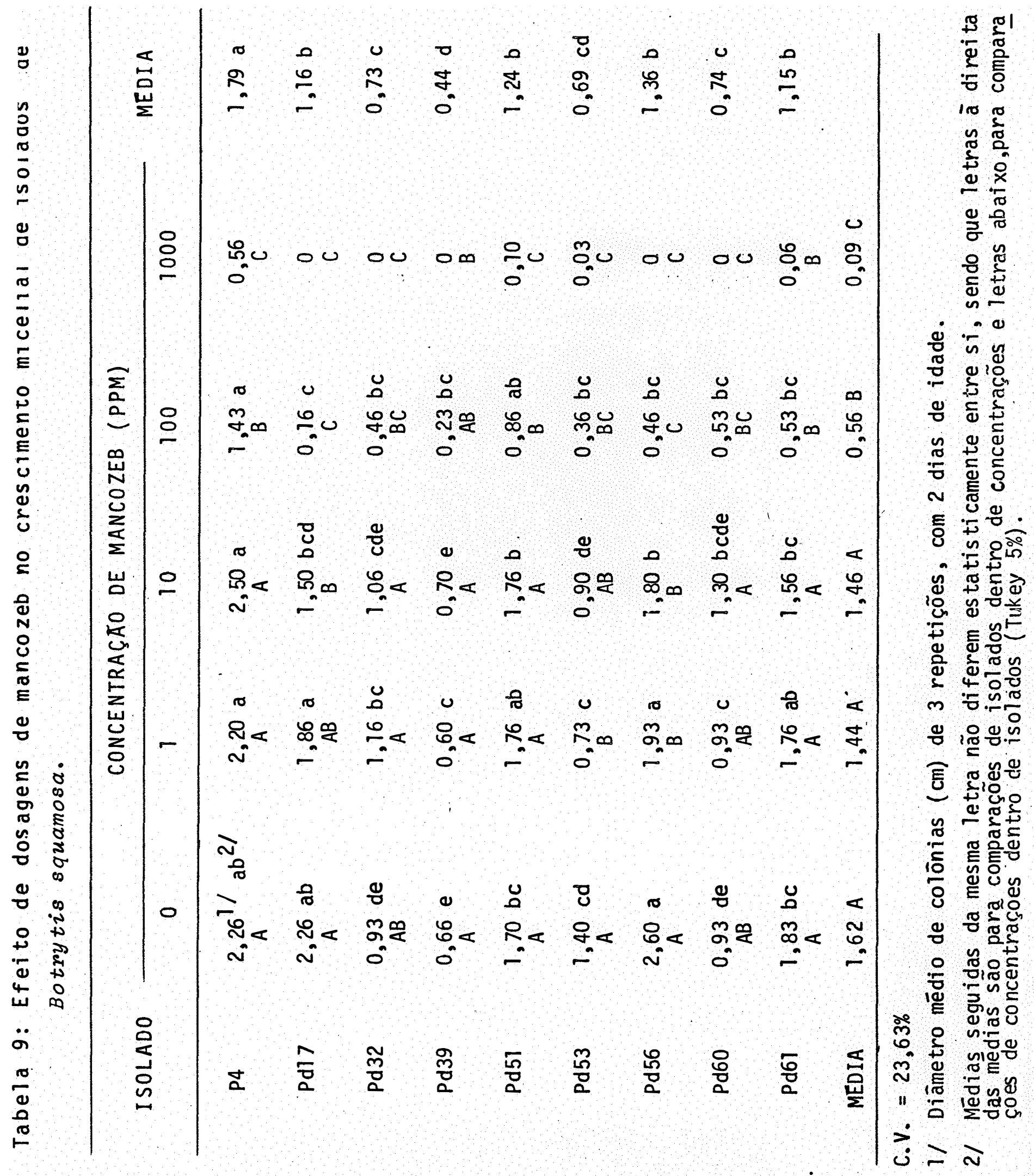


Tabela 10: Efeito de dosagens de procymidone no crescimento micelial de isolados de Botrytis squamosa.

\begin{tabular}{|c|c|c|c|}
\hline \multirow{2}{*}{ ISOLADO } & \multicolumn{2}{|c|}{ CONCENTRAÇAOO DE PROCYMIDONE (PPM) } & \multirow{2}{*}{ MEDIA } \\
\hline & 0 & 1 & \\
\hline P4 & $\underset{A}{1,76^{1 /} c^{2 /}}$ & $\begin{array}{c}0,33 \\
B\end{array}$ & $1,05 \mathrm{~b}$ \\
\hline Pd8 & $\underset{A}{1,40} \mathrm{~cd}$ & $\underset{B}{0,23}$ & $0,82 \mathrm{bc}$ \\
\hline $\mathrm{Pd} 77$ & $\underset{A}{3,10} a b$ & $\begin{array}{c}0,56 \\
B\end{array}$ & $1,83 \mathrm{a}$ \\
\hline Pd27 & $2,90 \mathrm{~b}$ & $\begin{array}{c}0,40 \\
B\end{array}$ & $1,65 \mathrm{a}$ \\
\hline Pd32 & $\underset{A}{3,16} a b$ & $\begin{array}{c}0,36 \\
B\end{array}$ & $1,77 \mathrm{a}$ \\
\hline $\mathrm{Pd} 44$ & $\begin{array}{c}1,83 \mathrm{c} \\
\mathrm{A}\end{array}$ & $\begin{array}{c}0,16 \\
B\end{array}$ & $1,00 \mathrm{~b}$ \\
\hline Pd58 & $\begin{array}{c}3,40 \\
A\end{array}$ & $\begin{array}{c}0,23 \\
B\end{array}$ & $1,82 a$ \\
\hline SCl9. & $\begin{array}{c}1,00 \mathrm{~d} \\
\mathrm{~A}\end{array}$ & $\begin{array}{c}0,26 \\
B\end{array}$ & $0,63 \mathrm{c}$ \\
\hline MEDIA & $2,32 \mathrm{~A}$ & $0,32 \mathrm{~B}$ & \\
\hline
\end{tabular}

C.V. $=14,08 \%$

1/ Diâmetro médio de colônias $(\mathrm{cm})$ de 3 repetições, com 2 dias de idade.

2) Médias seguidas da mesma letra não diferem estatis ticamente entre si, sendo que letras à direita das médias são para comparações de isolados dentro de concentrações e letras abaixo; para comparaçōes de concentrações dentro de isolados (Tukey $5 \%$ ). 
Tabela 11: Efeito de dosagens de propiconazol no crescimento micelial de isolados de Botrytis squamosa.

\begin{tabular}{|c|c|c|c|c|}
\hline \multirow{2}{*}{ ISOLADO } & \multirow{2}{*}{$\frac{\text { CONCENTRAÇAO }}{0}$} & \multicolumn{2}{|c|}{ DE PROPICONAZOL (PPM) } & \multirow{2}{*}{ MEDIA } \\
\hline & & 1 & 10 & \\
\hline P4 & $1,30^{1 /}$ ef ${ }^{2 /}$ & $\underset{B}{0,16 b c}$ & $\begin{array}{l}0 \\
B\end{array}$ & 0,49 de \\
\hline Pd8 & $\begin{array}{c}0,86 \mathrm{f} \\
\mathrm{A}\end{array}$ & $\begin{array}{ll}0 & C \\
B\end{array}$ & $\begin{array}{l}0 \\
B\end{array}$ & 0,29 e \\
\hline Pdl7 & $\begin{array}{c}3,40 \\
A\end{array}$ & $\underset{B}{0,90} a$ & $\begin{array}{c}0,13 \\
C\end{array}$ & 1,48 a \\
\hline Pd27 & $\begin{array}{c}2,40 \mathrm{bc} \\
A\end{array}$ & $\underset{B}{0,13} b c$ & $\begin{array}{l}0 \\
B\end{array}$ & $0,84 c$ \\
\hline Pd32 & $\begin{array}{c}2,56 b \\
A\end{array}$ & $\underset{B}{0,60} a b$ & $\begin{array}{c}0,33 \\
B\end{array}$ & $1,17 b$ \\
\hline Pd44 & $\underset{A}{1,50}$ de & $\begin{array}{ll}0 & C \\
B & \end{array}$ & $\begin{array}{l}0 \\
B\end{array}$ & 0,50 de \\
\hline $\operatorname{Pd} 58$ & $\underset{A}{1,93} \mathrm{~cd}$ & $\begin{array}{ll}0 & 6 \\
B & \end{array}$ & $\begin{array}{l}0 \\
8\end{array}$ & $0,64 \mathrm{~cd}$ \\
\hline SC19 & $\begin{array}{c}1,33 \text { ef } \\
A\end{array}$ & $\begin{array}{ll}0 & C \\
B & \end{array}$ & $\begin{array}{l}0 \\
\text { B }\end{array}$ & $0,44 \mathrm{de}$ \\
\hline MEDIA & $1,91 \mathrm{~A}$ & $0,23 \mathrm{~B}$ & $0,06 c$ & \\
\hline
\end{tabular}

C.V. $=25,20 \%$

1/ Diâmetro mëdio de colônias $(\mathrm{cm})$ de 3 repetições, com 2 dias de idade.

2) Mēdias seguidas da mesma letra não diferem estatisticamente entre si, sendo que letras à direita das mēdias são para comparações de isolados dentro de concentrações e letras abaixo, para comparações de concentrações dentro de isolados (Tukey $5 \%$ ). 


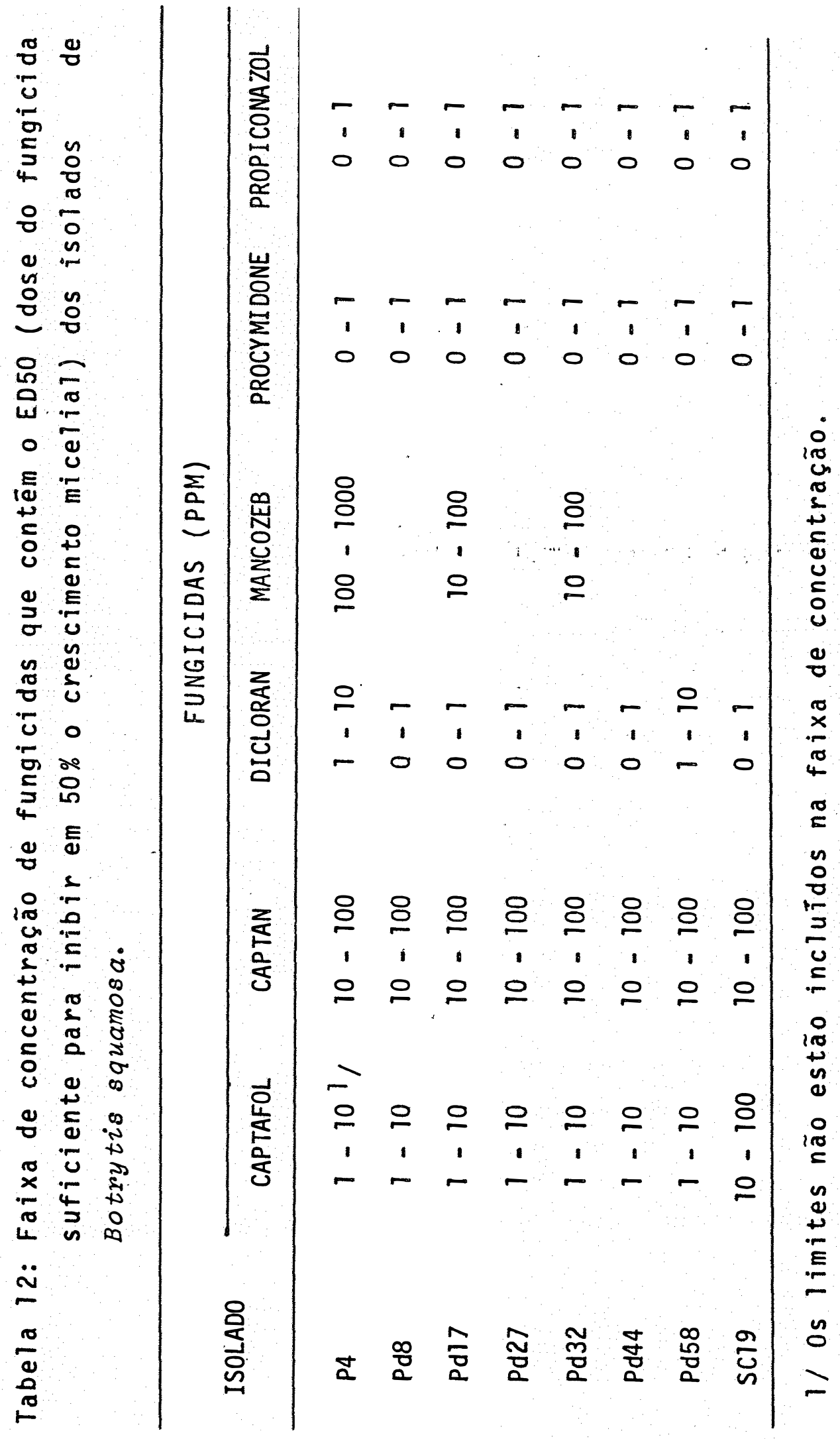




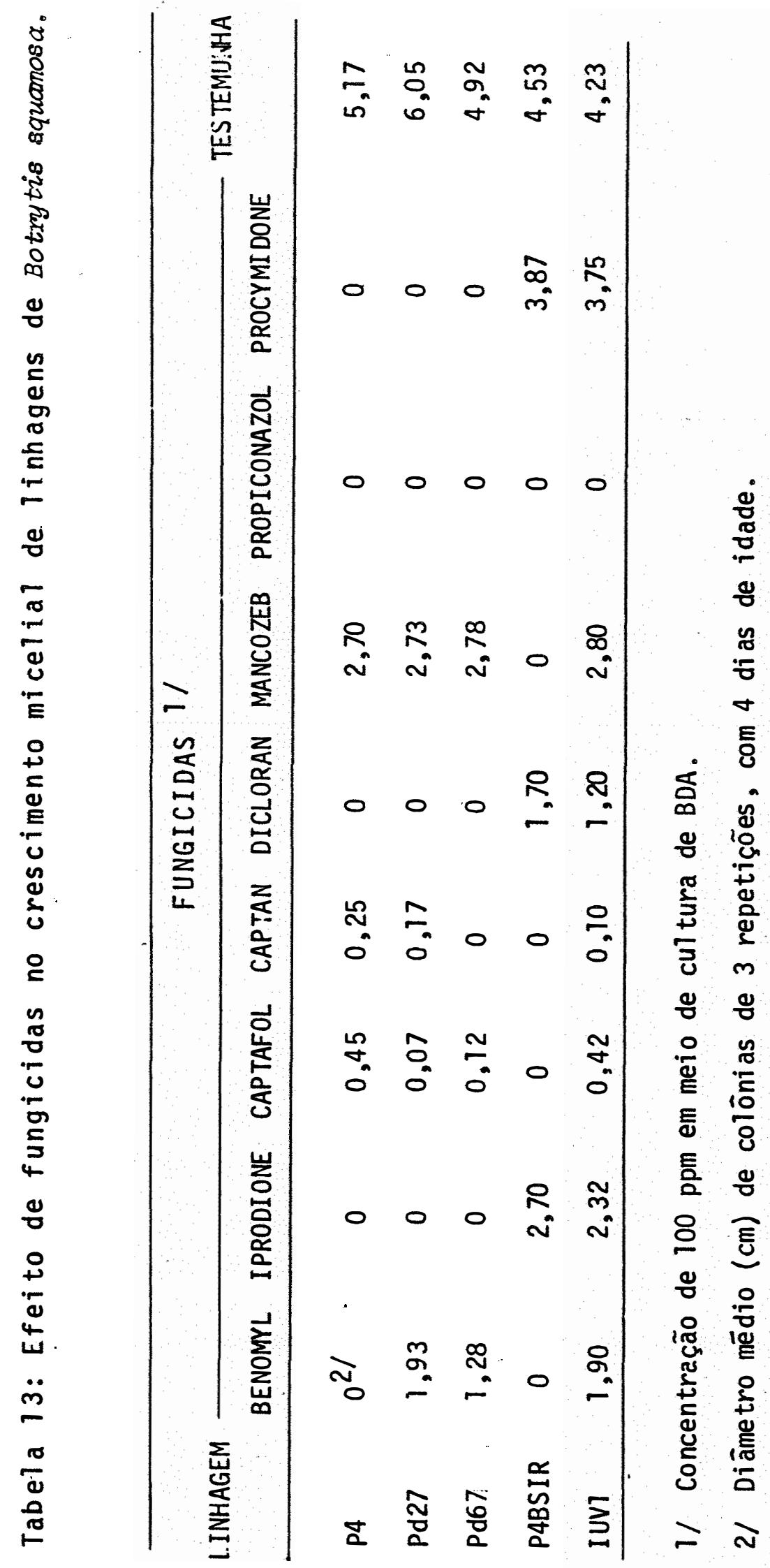


4.6. Adaptabilidade.

0 crescimento micèlial na ausência de fungici das dos isolados $P 4, P d 27$ e $P d 67$, sensiveis a dicarboximidas, seguiu taxas diārias maiores do que as observadas para as linhagens resistentes, P4BSIR e IUV1, que foram ob tidas em condiçōes de laboratōrio (tabela 14). Entre os :jsolados obtidos em condições de campo, $\mathrm{Pd} 27$, apresentou maior taxa de crescimento diārio, assim como maior produção de conĩdios (tabela 15).

Todas as linhagens testadas foram patogēnicas a plāntulas e discos de escamas de cebola, sendo que os isola dos P4 e Pd27 apresentaram maior porcentagem de folhas com queima das pontas (tabela 16) e maior número de discos com sintomas (tabera 17).

A competição in vitro entre isolados sensiveis e resistentes a benomyl resultou no desaparecimento da linhagem sensivel da mistura $P 4+P d 27$ e sua predomināncia na mistura $P 4+P d 67$ (tabela 18). Resultado semelhante foi ob tido na competição in vivo, nos dois experimentos realizados (tabelas 19 e 20). No experimento 1 , 0 isolado res is tente a benomyl (Pd27) predominou na segunda transferència de inōculo, entretanto $P d 64$ e $P d 67$, tambēm resis tentes a benomyl, 
desapareceram na primeira transferēncia, sendo que Pd65 não sofreu outras transferéncias devido a problemas de contamina ção com bactērias. No Experimento 2, da mesma forma, 0 isola do Pd27 predominou na segunda transferēncia de inōculo, entretanto, não foi observado o desaparecimento de Pd67 quando um maior nūmero de sub-culturas foi testado, apesar de uma redução em sua frequēncia na população. 


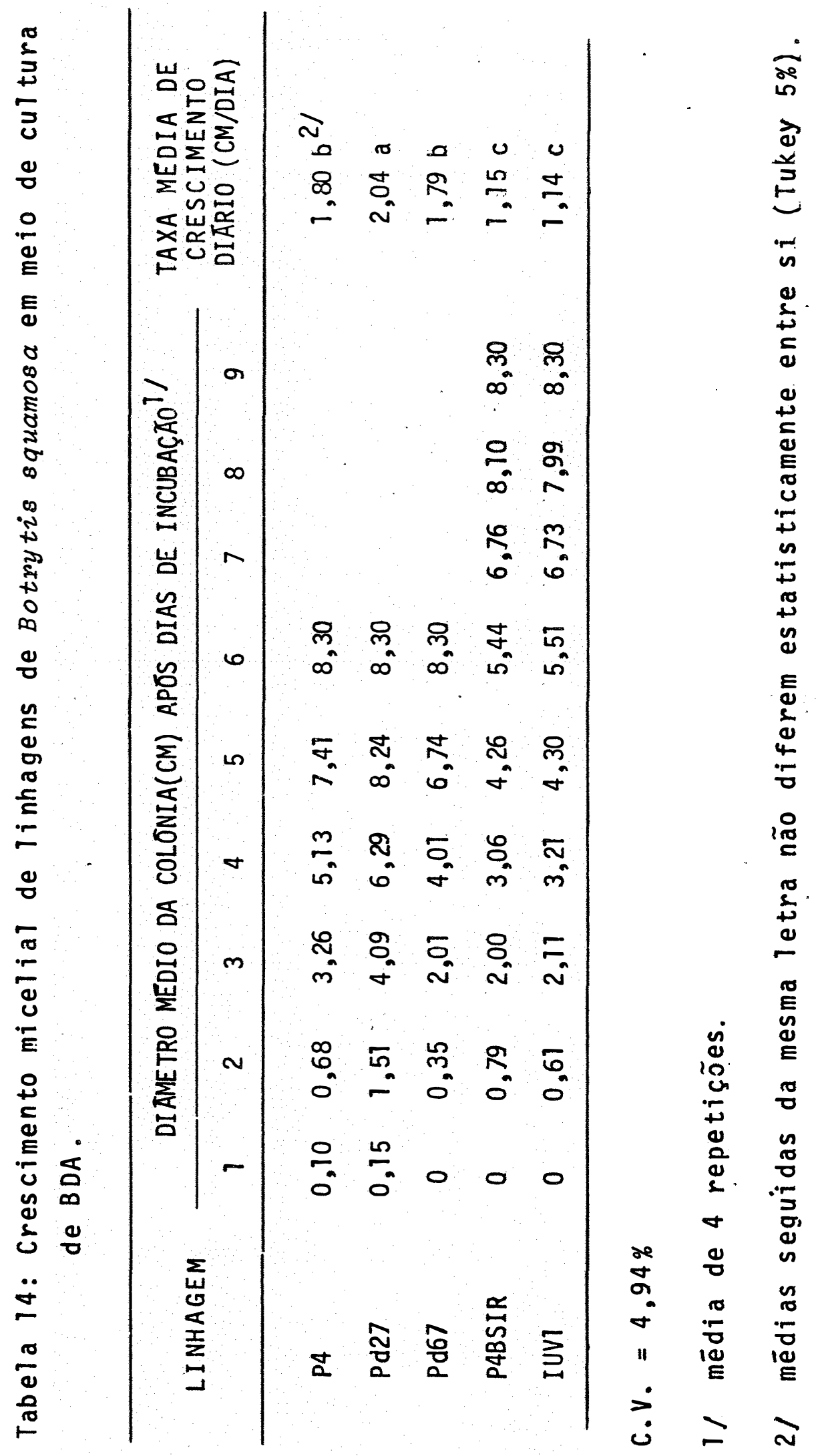


Tabela 15: Produção de conĩdios de linhagens de Botrytis squamosa.

LINHAGEM CONIDIOS/PLACA DE PETRI ${ }^{1 /}$

P4

$6,211 \cdot 10^{5} \quad b^{21}$

Pd27

$14,712.10^{5} \quad$ a

Pd6 7

$1,458.10^{5} \mathrm{~b}$

P4BSIR

$5,727.10^{5} \quad b$

IUVI

$2,292.10^{5} \quad b$

C.V. $=45,77 \%$

1/ Mēdia de 4 repetiçöes.

2/ Mēdias seguidas da mesma letra não diferem estatisticamente entre si (Tukey 5\%). 
Tabela 16: Patogenicidade de linhagens de Botrytis squamosa em plāntulas de cebola.

LINHAGEM

LINHAGEM

P4

Pd 27

$P d 67$

P4BSIR

IUVI
PORCENTAGEM DE

FOLHAS COM QUEIMA

DAS PONTAS $1 /$
$41,6 \mathrm{a}^{21}$

89,8 a

$25,4 \quad b$

$41,8 b$

$51,8 \mathrm{~b}$

C.V. $=8,86 \%$

$1 /$ Média de 2 repetições.

2) Médias seguidas da mesma letra não diferem estatisticamen te entre si (Tukey $5 \%$; dados transformados em arcsen $\sqrt{x}$ ). 
Tabela 17: Patogenicidade de linhagens de Botrytis squomosa em discos de escama de butbos de cebola.

\begin{tabular}{|c|c|c|c|c|}
\hline \multirow[b]{2}{*}{ LINHAGEM } & \multicolumn{2}{|c|}{3 DIAS APOS INOCULAÇAOO } & \multicolumn{2}{|c|}{6 DIAS APOS INOCULAÇĀO } \\
\hline & $\begin{array}{l}\text { DISCOS } \\
\text { COM } \\
\text { SINTOMAS }\end{array}$ & $\begin{array}{l}\text { DISCOS COM } \\
\text { CRESCIMENTO } \\
\text { MICELIAL }\end{array}$ & $\begin{array}{l}\text { DISCOS } \\
\text { COM } \\
\text { SINTOMAS }\end{array}$ & $\begin{array}{l}\text { DISCOS COM } \\
\text { CRESCIMENTO } \\
\text { MICELIAL }\end{array}$ \\
\hline P4 & 16 & 0 & 16 & 16 \\
\hline Pd27 & 16 & 0 & 16 & 15 \\
\hline$P d 67$ & 5 & 5 & 16 & 5 \\
\hline P4BSIR & 12 & 12 & 16 & 12 \\
\hline IUVI & 3 & 3 & 16 & 3 \\
\hline Tes temunh a & 0 & 0 & 0 & 0 \\
\hline
\end{tabular}


Tabela 18: Competição entre os isolados de Botrytis squamosa resistentes $(P d 27$ e $P d 67)$ e sensível (P4) a benomyl atravēs de transferēncias sucessivas de suspensões de conídios in vitro na ausência do fungicida.

\begin{tabular}{|c|c|c|c|c|c|c|}
\hline \multirow{2}{*}{$\begin{array}{l}\text { ISOLADOS E } \\
\text { KISTURAS } \\
\text { (1+1) de B. } \\
\text { squamosa }\end{array}$} & \multicolumn{3}{|c|}{ 1. TRANSFERENCIA } & \multicolumn{3}{|c|}{ 2. TRANSFERENCIA } \\
\hline & $\begin{array}{l}\text { TOTAL DE } \\
\text { SUBCULTURAS } \\
\text { TESTADAS }\end{array}$ & $\begin{array}{l}\text { SUBCULTURAS } \\
\text { RESISTHNTES A } \\
\text { BENONYL }\end{array}$ & $\begin{array}{c}\text { PORCENTAGEM } \\
\text { DE } \\
\text { SUBCULTURAS } \\
\text { RESISTENTES }\end{array}$ & $\begin{array}{l}\text { TOTAL DE } \\
\text { SUBCULTURAS } \\
\text { TESTADAS }\end{array}$ & $\begin{array}{l}\text { SUBCULTURAS } \\
\text { RESISTENTES A } \\
\text { BENOMYL }\end{array}$ & $\begin{array}{c}\text { PORCENTAGEM } \\
\text { DE } \\
\text { SUBCULTURAS } \\
\text { RESISTENTES }\end{array}$ \\
\hline$P_{4}$ & 3 & 0 & 0 & . & & \\
\hline Pd27 & 3 & 3 & 100 & & & \\
\hline Pa67 & 3 & 3 & 100 & & & \\
\hline $\mathrm{Pd} 27+\mathrm{P} 4$ & 36 & 36 & 100 & & & \\
\hline$P d 67+P 4$ & 38 & 4 & 11 & 12 & 0 & 0 \\
\hline
\end{tabular}


Tabela 19: Competição entre os isolados de Botrytis squamosa resistentes $(P d 27, P d 64, P d 65, P d 67)$ e sens,ível (P4) a benomyl atravēs de transferēncias sucessivas de inōculo em plàntulas de cebola, na ausència do fungicida (Experimento 1).

\begin{tabular}{|c|c|c|c|c|c|c|}
\hline \multirow[b]{2}{*}{$\begin{array}{l}\text { ISOLADOS E } \\
\text { UISTURAS } \\
(1+1) \text { de B } \\
\text { squamosa }\end{array}$} & \multicolumn{3}{|c|}{ 19 TRANSFERENCIA } & \multicolumn{3}{|c|}{ 20 TRANSFERENCIA } \\
\hline & $\begin{array}{l}\text { TOTAL DE } \\
\text { SUBCULTURAS } \\
\text { TESTADAS }\end{array}$ & $\begin{array}{l}\text { SUBCOLTURAS } \\
\text { RESISTENTES A } \\
\text { BENOMYL }\end{array}$ & $\begin{array}{c}\text { PORCENTAGEM } \\
\text { DE } \\
\text { SUBCULTURAS } \\
\text { RESISTENTES }\end{array}$ & $\begin{array}{l}\text { TOTAL DE } \\
\text { SUBCULTURAS } \\
\text { TESTADAS }\end{array}$ & $\begin{array}{l}\text { SUBCULTURAS } \\
\text { RESISTENTES A } \\
\text { BENOMYL }\end{array}$ & $\begin{array}{c}\text { PORCENTAGEM } \\
\text { DE } \\
\text { SUBCULTURAS } \\
\text { RESISTENTES }\end{array}$ \\
\hline P4 & 4 & 0 & 0 & & & \\
\hline $\mathrm{Pd} 27+\mathrm{P} 4$ & 25 & 17 & .68 & 32 & 32 & 100 \\
\hline $\mathrm{Pd} 64+\mathrm{P4}$ & 28 & 0 & 0 & & . & \\
\hline $\mathrm{P} 265+\mathrm{P} 4$ & 32 & 6 & 19 & & & \\
\hline $\mathrm{Pd} 67+\mathrm{P} 4$ & 3 & 0 & 0 & & & \\
\hline
\end{tabular}


Tabela 20: Competição entre os isolados de Botrytis squomosa resistentes $(P d 27$ e $P d 67)$ e sensível ( $P 4)$ a benomy atravēs de transferēncias sucessivas de inōculo em plāntulas de cebola, na ausência do fungicida (Experimento 2).

\begin{tabular}{|c|c|c|c|c|c|c|}
\hline \multirow[b]{2}{*}{$\begin{array}{l}\text { ISOLADOS E } \\
\text { MISTURAS } \\
(1+1) \text { de B. } \\
\text { squamosa }\end{array}$} & \multicolumn{3}{|c|}{ 18 TRANSFERENCIA } & \multicolumn{3}{|c|}{ 28 TRANSFERTANCIA } \\
\hline & $\begin{array}{l}\text { TOTAL DE } \\
\text { SUBCULTURAS } \\
\text { TESTADAS }\end{array}$ & $\begin{array}{l}\text { SUBCULTURAS } \\
\text { RESISTENTES A } \\
\text { BENOMYL }\end{array}$ & $\begin{array}{c}\text { PORCENTAGEM } \\
\text { DE } \\
\text { SUBCULTURAS } \\
\text { RESISTENTES }\end{array}$ & $\begin{array}{l}\text { TOTAL DE } \\
\text { SUBCULTURAS } \\
\text { TESTADAS }\end{array}$ & $\begin{array}{l}\text { SUBCULTURAS } \\
\text { RESISTENTES A } \\
\text { BENOMYL }\end{array}$ & $\begin{array}{c}\text { PORCENTAGEM } \\
\text { DE } \\
\text { SUBCULTURAS } \\
\text { RESISTENTES }\end{array}$ \\
\hline P4 & 5 & 0 & 0 & & & \\
\hline $\operatorname{Pd} 27$ & 5 & 5 & 100 & & & \\
\hline Pd67 & 5 & 5 & 100 & & & \\
\hline $\mathrm{Pd} 27+\mathrm{P4}$ & $2 b$ & 10 & 67 & 12 & 12 & 200 \\
\hline $\mathrm{Pd} 67+\mathrm{P} 4$ & 22 & 10 & 45 & 16 & 1 & 6 \\
\hline
\end{tabular}


0 isolado Pd44 permaneceu resistente a benomyl apōs cinco gerações de transferēncias monospōricas, na ausẹn cia do fungicida, não havendo o surgimento de nenhuma subcul tura sensível, demonstrando a estabil idade da resistência a benomyl (tabela 21). Da mesma forma, a linhagem duplo-resis tente IUVI permaneceu resistente a benomy 1 e iprodione após sucessivas transferēncias monospóricas in vitro (tabela 22).

4.7. Anas tomose de hifas.

A observação da presença ou não de anastomose entre hifas de diferentes linhagens de $B$. squamosa está apre sentada na tabela 23. Houve formação de anastomose em todas as combinações de linhagens testadas, exceto nas que continham 0 isolado Pd64.

4.8. Coloração de nūcleos de conīidios

0 isolado resistente a benomy $(P d 27)$ e o sen sĩvel (P4) apresentaram semelhante nümero de nūcleos por conĩdio, ou seja, até. 20 nūcleos. 


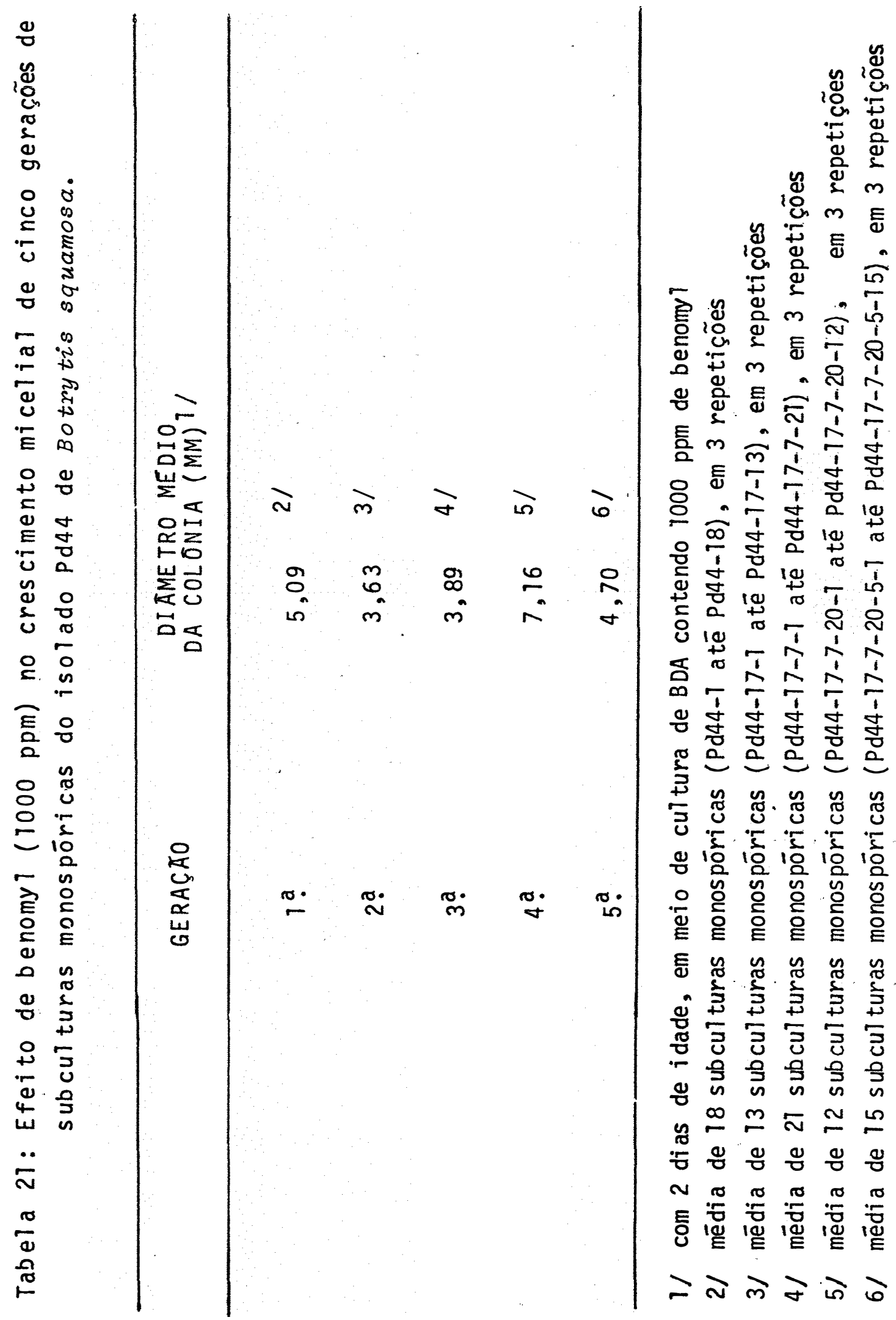




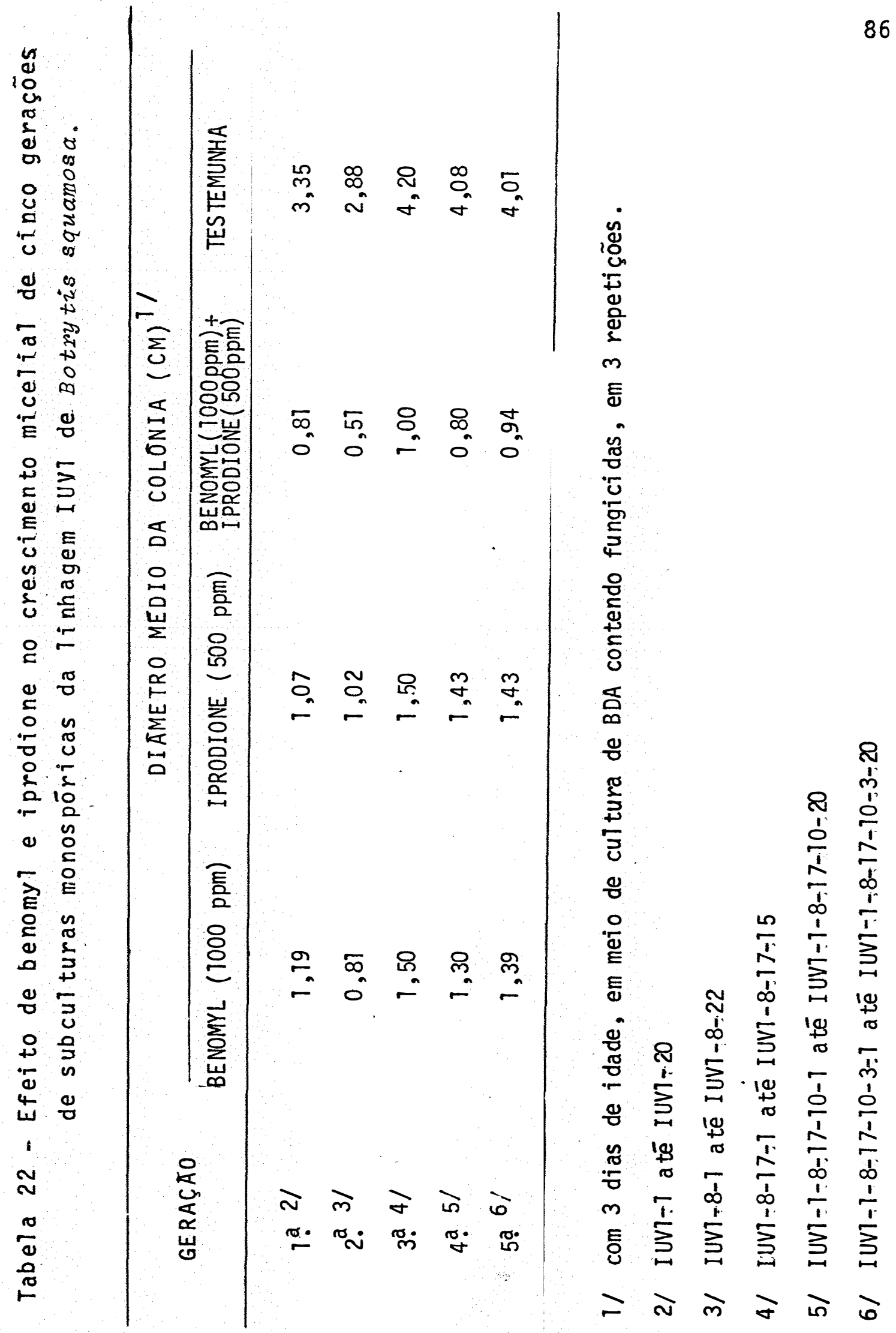


Tabela 23: Formação de anastomose entre hifas de linhagens de Botrytis squamosa.

LINHAGENS FORMAÇÃO DE ANAS TOMOSE
DE HIFAS

$P d 27$ - Pd27

$+1 \%$

$P d 27-P d 65$

$+$

Pd27 - IUV2

$P d 67$ - $P d 67$

$P d 67-P d 46$

$P d 67$ - $P d 64$

$P 4 \quad-P 4$

$P 4 \quad-P d 27$

P4 - Pd46

P4 - Pd64

$P 4 \quad-P d 65$

P4 - Pd67

P4 - IUV2 
5. DISCUSSÃO

Do levantamento de frequēncia de resistência a benomyl dos isolados de $B$. squamosa, ficou demonstrado que a pressão de seleção exercida pela aplicação deste fungicida deu origem ao desenvolvimento de linhagens resistentes. Assim sendo, P4 e P5, obtidos em Piracicaba (SP), em culturas onde este fungicida não foi utilizado, apresentaram-se sensĩveis a benomyl. Por outro lado, os isolados procedentes de culturas onde tal fungicida foi utilizado, isto é, do Munici pio de Piedade (SP), comportaram-se como resistentes ao produto, como ocorreu con diversos patógenos em diferentes culturas onde este produto foi utilizado (DAVIDSE, 1982). Alēm disso, houve uma diferença acentuada entre o nivel de resistência das linhagens resistentes $(1000 \mathrm{ppm})$ e as. sensĩveis (1 ppm), sem a constatação de resistência intermediāria, como tambēm foi observado por diversos autores (GEORGOPOULOS \& DOVAS, 1973; MILLER \& FLETCHER, 1974; GEESON, 1976; CH0,1977; GRINDLE, 1979; PRESLY \& MAUDE, 1980a e RUPPEL et alii,1980).

Para iprodione, a situação verificada foi diferente da constatada para benomy 1 . Todos os isolados testa- 
dos apresentaram-se sensīveis a este fungicida. 0 mesmo ocor reu, segundo LORBEER? ', em culturas comerciais de cebola em New York (USA), onde houve problemas com o surgimento de $1 \mathrm{i}$ nhagens de $B$. squamosa resistentes a benomyl logo após a introdução deste produto, enquanto que os dicarboximidas, apōs anos de uso, não apresentaram tais problemas.

No presente trabalho não foi obtida uma linha gem resistente a benomyl a partir de uma sensivel, como também ocorreu com GEESON (1976), entretanto foi obtida por POLACH \& MOLIN (1975). Todavia, foram obtidas linhagens res is tentes a iprodione em condiçôes de laboratório, apesar da não ocorréncia em condições de campo, como tem sido observado,de modo geral, com os dicarboximidas (BEEVER \& BYRDE, 1982).

Segundo DEKKER (1982), a emergēncia in vitro de 1 inhagens resistentes a um fungicida não implica que 0 uso deste produto no campo resultarā em falha do controle da doença, sendo que tal fato depende da adaptabilidade do mutante resistente e da pressão de seleção. No presente trabaTho, o estudo da adaptabilidade das linhagens de $B$. squamosa, sensiveis e resistentes a benzimidazóis edicarboximidas, pode explicar a frequēncia de resistência a estes fungicidas

1 LORBEER, J. W. (Department of Plant Pathology, Cornell University, New York, USA) Comunicação pessoal, 1985. 
constatada em condições de campo.

Houve variação na adaptabilidade dos isolados de $B$. squamosa resistentes a benzimidazóis, is to ē; $\quad$ isolado Pd27 apresentou maior capacidade de crescimento, es porulação, patogenicidade e competição com a linhagem sensĩvel do que o isolado Pd67. Dessa forma, tais caracteristicas do isolado Pd27 demonstram que linhagens resistentes a beno. myl podem ser tão ou mais adaptadas do que as sensíveis, con ferindo-lhes, assim, capacidade de predominar e permanecer na população do patógeno. Por outro lado, as linhagens estudadas de $B$. squamosa resistentes a dicarboximidas apresentaram menor adaptabilidade do que os isolados sensiveis, sendo esta a possĩvel razão da não ocorrēncia de tais isolados em condições de campo.

Apesar do método utilizado para estudar a com petição in vivo entre as linhagens resistentes e sensiveis não avaliar a competição quanto a disseminação e sobrevivēncia do patógeno, os resultades obtidos refletiram as diferenças das linhagens quanto a adaptabilidade. 0 isolado Pd 27 , resistente a benomyl, predominou na população do fungo após poucàs transferências de inōculo, mesmo na ausēncia de pres são de seleção causada pelo uso deste fungicida, sendo que tal situaçăo pode estar ocorrendo em condições de campo. 0 
isolado Pd67, tambēm resistente a benomyl, foi eliminado da população no Experimento 1 (tabela 19), entretanto, quando foi testado um maior nümero de subculturas (tabela 20), sua frequência foi reduzida na população, mas não eliminado. Tal fato pode ser devido a ocorrēncia de anastomose de hifas, on de nūcleos conferindo resistēncia aos benzimidazóis poderiam ter sido doados ao isolado sensivel(P4), como foi observado in vitro (tabela 23). Da mesma forma, a ausēncia de anastomo se de hifas observada in vitro entre os isolados P4 e Pd 64 pode explicar o desaparecimento de Pd 64 na competição in vi vo com P4 (tabela 19).

Além da pressão de seleção e adaptabilidade da 1 inhagem resistente, segundo DEKKER (1982), a velocidade de surgimento do problema de resistēncia de fungos a fungicidas depende do tipo de doença, da natureza do patógeno e das circunstāncias que promovem ou dificultam o desenvolvimento da resistēncia. Entre esses fatores, o referido autor cita : a) capacidade de multiplicação e disseminação do patō geno, visto que o surgimento de resistēncia deve ser mais rāpido em patógenos com abundante esporulação em partes aéreas da planta do que em patógenos que esporulam pouco ou produzem esporos que não são facilmente transportados, como pode ser o caso de vārios patógenos de raīzes; b) sobrevivēncia da linhagem sensīvel, pois durante os períodos de reduzida 
pressão de seleção, esta linhagem poderā competir coma linhagem resistente, como $\bar{e}$ o caso das murchas vasculares e dos patōgenos de raízes, nas quais os patógenos são dificilmente atingidos por fungicidas aplicados em pulverizações; c) limiar de infecção da doença, jā que com doenças com um al to limiar de infeção, o surgimento de uma cēlula mutante raramente resultarā em infecção, assim o risco de desenvol vimento de resistēncia na população é baixo; d) cēluras multi-nucleadas, visto que genes que conferem resistēncia em fungos multi-nucleados podem, sob pressão de seleção do fungicida, ter sua frequencia rapidamente aumentada na população do patógeno, como nos fungos heterocarióticos; e) severi dade da epidemia, visto que em vārios casos, os fungicidas, apesar de apresentarem controle satisfatório da doença em di versos ànos, falharam em estações nas quais ocorreram severas epidemias.

No caso da Queima das Pontas da cebola, as ca racterísticas da doença permitem e favorecem o desenvolvimento de resistência a fungicidas. Is to porque è uma doença foliar, causada por um patōgeno que produz conĩdios facilmen te disseminados e que apresenta uma grande variabilidade gene tica devido a ocorrência de heterocariose.

0 efeito da heterocariose na resistência de 
B. cinerea a dicloran foi estudado por WEBSTER et alii (1970). Esses autores selecionaram, in vitro, linhagens praticamente homocarióticas quanto a resistēncia a dicloran a partir de linhagens sensiveis. Por ser um fungo heterocariōtico, face a uma pressão de seleção, os nūcleos podem ser selecionados no micēlio de uma linhagem.

A seleção de linhagens sensíveis a partir das resistentes não foi verificada no presente trabalho, visto que as linhagens resistentes a benomyl e duplo - resistente apresentaram-se estāveis, mesmo após sucessivas transferēncias monospöricas. Da mesma forma, pode-se verificar que os isolados Pd64, Pd65, Pd66 e Pd67 mostraram-se resistentes a benomyl, mesmo sendo isolados em um campo onde o produtor deixou de utilizar esse produto (tabela 1), evidenciando a estabilidade da resistēncia.

Para GEORGOPOULOS (1982), quando ocorre faTha no controle de uma doença devido ao desenvolvimento de resistēncia do patógeno a um fungicida, na prātica é impor tante verificar se a efètividade de outros fungicidas foi afetada. Se uma mutação afeta a sensibilidade a um produto $e$ não a outro, os dois compostos são ditos não correlacionados em termos de resistēncia cruzada. Uma corre?ação positiva existe quando o mutante é menos sensīvel ou menos resistente 
aos dois compostos do que a linhagem selvagem. Se o mutante $\bar{e}$ mais resistente do que a linhagem selvagem a um produto químico e mais sensível a outro produto, trata-se de uma resistência cruzada negativamente correlacionada. Entretanto, quando uma linhagem è resistente a dois diferentes fungicidas devido a duas mutações independentes, os dois compostos não são correlacionados, visto que a resistêncía cruzada não pode ser suposta sem evidencias de que a sensibilidade aos dois produtos é controlada pelo mesmo gene.

O estudo da sensibil idade colateral dos isola dos de $B$. squamosa mostrou que a resistência a iprodione acar reta em resistēncia a procymidone e dicloran, isto é, hā resistência cruzada entre esses fungicidas. Pouco ou nenhum crescimento foi observado para captafol e captan, sendo que propiconazol, pertencente ao grupo dos inibidores da síntese do esterol, não permitiu o crescimento de nenhuma linhagem (tabela 13).

Embora não tenham havido perdas associadas com o desenvolvimento de resistência a dicarboximidas, BEEVER \& BRIEN (1983) afirmam que há evidèncias de que a presença de linhagens resistentes pode levar à redução da eficācia do fungicida e, sob condições de alta pressão de doença, não controle da doença. Além disso, a longo termo, com a exposi- 
ção de linhagens com baixo nĩvel de resistência a seleção do fungicida, pode ocorrer aumento da adaptabilidade e do grau de resistência.

Segundo STAUB \& SOZZI (1984), quando hä risco de desenvolvimento de resistência do patōgeno, a pressão de seleção do fungicida deve ser reduzida atravēs da aplicação de outras medidas de controle, reduzindo o período de expos ção do patōgeno ao fungicida. Para DEKKER (1982), a pressão de seleção deve ser reduzida restringindo-se a aplicação do fungicida vulnerável a períodos crīticos; reduzindo a quantị. dade aplicada e a frequência de aplicação; limitando a ārea tratada com o fungicida isoladamente; utilizando um método de aplicação que reduza a exposição do patógeno ao fungici. da; usando dois fungicidas específicos, de diferentes modos de ação, em sequência e não em mistura; e realizando monitoramento para detectar a presença de linhagens resistentes.

Segundo KIMATI (1987), apōs o advento dos fun gicidas sistêmicos, o monitoramento da resistência tornou-se indispensāvel. Para STAUB \& SOZZI (1984), o monitoramento po de ser útil: 1) durante o desenvolvimento e introdução de um novo fungicida, avaliando a vulnerabilidade do produto; apōs a introdução no mercado, analisando riscos de falha de eficiência devido ao desenvolvimento de resistência; 3) acom 
panhando a resistēncia nas condições de campo, verificando o sucesso das estratégias anti-resistência; e 4) determinando a estabilidade da resistēncia, ano após ano, depois da retirada do fungicida. Dessa forma, o estudo da resistência de fungos a fungicidas deve ser contínuo, com a finalidade de assegurar o controle da doença. 
6. CONCLUSOES

Do presente trabalho podem ser tiradas as seguintes conciusões:

1. A resistência de $B$. squamosa a benomyl se encontra amplamente difundida. De um total de 29 isolados provenientes de campos comerciais de cebola, 27 foram resistentes atē 1000 ppm de benomyl.

2. A resistência de $B$. squamosa a iprodione ainda não ocorre nas condições de cultura comercial, sendo todos os isola dos completamente inibidos a 100 ppm e a maioria a 10 ppm deste fungicida.

3. Linhagens de $B$. squamosa resistentes a iprodione podem ser facilmente obtidas da linhagem sensivel por semeadura densa de conídios em meio de cultura contendo 500 ppm do fungicida.

4. Linhagens de $B$. squamosa resistentes a benomyl + iprodione podem ser obtidas a partir de linhagens benomyl - resis tentes atravēs de irradiação ultravioleta e transferēn- 
cias sucessivas em meios de cultura com gradiente de ipro dione.

5. Linhagens de $B$. squamosa resistentes a iprodione foram tambēm resistentes a procymidone e dicloran.

6. Linhagens resistentes a benomyl, a iprodione e a iprodione + benomyl não tiveram alteradas suas sensibilidades ao fungicida propiconazol, porém houve uma tendência geral de se mostrarem mais sensíveis ao captan, captafol e mancozeb do que a linhagem sensivel.

7. Linhagens de $B$. squamosa resistentes a benomyl podem ser tão adaptadas quanto as sensĩveis, por outro lado linhagens resistentes a iprodione e a duplo-resistente tiveram reduzida sua adaptabilidade, com relação ao crescimento micelial, produção de coñ̃dios, patogenicidade e competição in vivo e in vitro.

8. Linhagens de $B$. squamosa resistentes a benomyl e iprodione podem ou não formar anastomoses de hifas com as sensiveis.

9. O nūmero de nūcleos/conīdios não diferiu entre a linhagem sensível e a resistente, sendo de até 20 nūcleos/conĩdio. 
7. REFERENCIAS BIBLIOGRAFICAS

BAILLY, R. \& DUBOIS, G. Index phytosanitaire. 17. ed. Paris, ACTA, 1981.479 p.

BARNETT, H. L. \& HUNTER, B. B.I IZ ustrated genera of imperfect fungi. 3. ed. Minneapolis, Burgess, 1972. 241 p.

BARROS, J. P. de. Anālise citogenētica de algumas linhagens de Aspergizzus nidulans (Eidem) Winter. Piracicaba, 1977.81p. (Mestrado - Escola Superior de Agricultura "Luiz de Quei roz" (USP).

BEEVER, R. E. \& BRIEN, H. M. R. A survey of resistance to the dicarboximide fungicides in Botrytis cinerea. New zeal and Journal of Agricultural Research, Wellington, 26 : $391-400,1983$.

BEEVER, R. E. \& BYRDE, R. J.W. Resistance to the dicarboximide fungicides. In: DEKKER, J.\& GEORGOPOULOS, S. G., ed. Fungicide resistance in crop protection. Wageningen, Centre for Agricultural Publishing and Documentation, 1982. p. $101-17$. 
BERQUIST, R. R. \& LORBEER, J. W. Genetics of variation in Botryotinia squamosa. Mycologia, New York, 63: 36-47, 1973 .

BERGQUIST, R. R; HORST, R. K.; LORBEER, J.W. Influence of polychromatic light, carbohydrate source, and $\mathrm{pH}$ on conidiation of Botryotinia squamosa. Phytopathology, st. Paul, 62: 889-95, 1972 .

BOLLEN, G. J. \& SCHOLTEN, G. Acquired resistance to benomy 1 and some other systemic fungicides in a strain of Botrytis cinerea in cyclamen. Netherlands Journal of Plant Pathology, Wageningen, $77: 83-90,1971$.

BOLTON, A. T. Fungicide resistance in Botrytis cinerea, the result of selective pressure on resistant strains already present in nature. Canadian Journal of Plant Science, Ireland, 56: 861-4, out. 1976 .

BORCK, K. \& BRAYMER, H. D. The genetic analys is of resistance to benomyl in Neurospora crassa. Journal of General Microbiology, London, 85:51-6, 1974 .

BRASIER, C.M. \& GIBBS, J. N. MBC tolerance in aggressive and non-aggressive isolates of Ceratocystis ulmi. Annals of Applied Biology, Wellesbourne, 80:231-5, 1975. 
CABRINI, H. M. Ocorrēncia de isolados de Botrytis cinerea Pers. ex. Fr. resistentes. a benomyl em morangos (Fragaria spp.) no Estado de São Paulo, Piracicaba, 1985.66p. (Mes trado - Escola Superior de Agricultura "Luiz de Queiroz"/ USP).

CHASTAGNER, G. A. \& OGAWA, J. M. DCNA - benomyl mul tiple tolerance in strains of Botrytis cinerea. Phytopathology, St. Pau1, 69 (7):699-702, 1979 .

CHASTAGNER, G. A. \& VASSEY, W. E. Tolerance of Botrytis tulipae to glycophene and vinclozolin. Phytopathology, St. Paul,69 (8):914, 1979 .

CHO, J. J. Shoot and flower blight of Leucospermum cordifolium incited by a benomyl - tolerant strain of Botrytis cinerea. Phytopathology, St. Paur, 67:124-7, jan. 1977.

CLEMONS, G. P. \& SISLER, H. D. Formation of a fungitoxic derivative from Benlate. Phytopathology, St.Paul, 59:705, mai. 1969.

COOKE, K; LOEFFLER, R.S.T.; PAPPAS, A. C. The structural rearrangement of iprodione in ethanolic solution. Pesticide Science, 0xford, 10:393-8, 1979 . 
DAVIDSE, L.C. Benzimidazole compounds: selectivity and resistance. In: DEKKER, J. \& GEORGOPOULOS, S.G., ed. Fungicide resistance in crop protection. Wageningen, Centre for Agricultural Publishing and Documentation, 1982. p.60-70.

DAVIDSE, L. C. \& FLACH, W. Differential binding of methyl benzimidazol -2- yl carbamate to fungal tubulin as a mechanism of resistance to this antimitotic agent in mutant strains of Aspergizzus niduzans. The Journal of Cezl Biology, New York, 72: 174-93, 1977.

DAVIS, R. P. \& DENNIS, C. Properties of dicarboximide-res is tant strains of Botrytis cinerea. Pesticide Science, oxford 12: $521-35,1981 \mathrm{a}$.

DAVIS; R. P. \& DENNIS, C. Studies on the survival and infective ability of dicarboximide-resistant strains of Botrytis cinerea. Annals of Applied Biology, Wellesbourne 98: $395-402,1981 \mathrm{~b}$.

DEKKER, J. Acquired resistance to fungicides. Annual Review of Phytopathology, Palo Al to, 14:405-28, 1976 .

DEKKER, J. Resistance. In: MARSH, R. W. Systemic Fungicides 2. ed. London, Butler \& Tanner, 1977. cap. 9, p. 176-97. 
DEKKER, J. \& GEORGOPOULOS, S. G. Fungicide resistance in crop protection. Wageningen, Centre for Agricultural Publishing and Documentation, 1982. 265p.

DELP, C. J. Coping with resistance to plant disease control agents. Plant Disease, St. Paul, 64 (7):652-7, 1980 .

DENNIS, C. \& DAVIS, R. P. Tolerance of Botrytis cinerea to iprodione and vinclozolin. Plant. Pathology, 0xford, 28; 1313,1979 .

DOYAS, C.; SKYLAKAKIS, G; GEORGOPOULOS, S. G. The adaptability of the benomyl-resistant population of Cercosporabeticola in Northern Greece. Phytopathology; St. Paul, 66: 1452-6 dez. 1976 .

EDGINGTON, L.V. Structural requirements of sys temic fungicides Annual Review of Phytopathology, Palo Alto, 19: 107-24, 1981 .

EDGINGTON, L. V.; KHEW, K.L.; BARRON, G.L. Fungitoxic spectrum of benzimidazole compounds. Phytopathology, St. Paul, 61: $42-4$, jan. 1971 .

EDGINGTON, L. V.; MARTIN, R.A.; BRUIN, G.C; PARSONS, I.M. Systemic fungicides: a perspective after 10 years. Plart Disease, St. Paul, 64 (1): 19-23, 1980 . 
FIgUEIREDO, M.B. Estudos sobre a aplicação do método de Castellani para conservação de fungos patógenos em plantas. 0 Biológico, São Paulo, 33: 9-13,.1967.

FIGUEIREDO, M. B. \& PIMENTEL, C.P.V. Mētodos utilizados para conservação de fungos na micoteca da Seção de Micologia Fí topatológica do Instituto Biológico. Summa Phytopathologica, Piracicaba, 1: 299-302, 1975.

FLETCHER, J. T. \& SCHOLEFIELD, S.M. Benomyl tolerance in isolates of Botrytis cinerea from tomato plants. Annals of Applied Biology, Well esbourne, 82: 529-36, 1976.

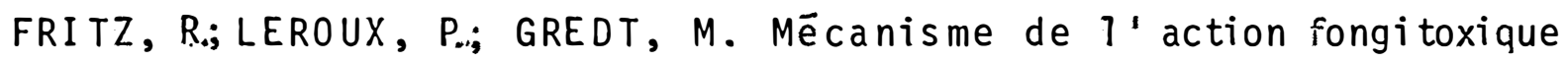
de la promidione (26019 RP ou glycophène), de la vinchlozoline et du dicloran sur Botrytis cinerea Pers. Phytopathologische Zeitschrift, Berlin, 90: 152-63,1977.

GEERSON, J. D. Comparative studies of methyl - benzimidazol -2- yl-carbamate-tolerant and sensitive isolates of Botrytis cinerea and other fungi Transactions British Mycological Society, London, 66, (1). 123-9, 1976.

GEORGOPOULOS, S.G. Cross-resistance. In: DEKKER, J.\& GEORGOPOULOS, S. G., ed. Fungicide resistance in crop protection. Wageningen, Centre for Agricultural Publishing and Documentation, $1982 \mathrm{a}$. p. 53-9. 
GEORGOPOULOS, S. G. Genetical and biochemical background of fungicide resistance. In: DEKKER, J. \& GEORGOPOULOS,S.G., ed. Fungicide resistance in crop protection. Wageningen, Centre for Agricultural Publishing and Documentation, $1982 \mathrm{~b}$. p. $46-52$.

GEORGOPOULOS, S. G. The problem of fungicide resistance. Bioscience, Arlington, 19 (11): 971-3, nov. 1969.

GEORGOPOULOS, S. G. \& DOVAS, C. A serious outbreak of strains of Cercospora beticola resistant to benzimidazole fungicides in Nor thern Greece. Plant Disease Reporter, Washington, 57 (4): 321-4, abr. 1973.

GEORGOPOULOS, S. G.; SARRIS, M.; ZIOEAS, B.N. Mitotic instability in Aspergizzus nidulans caused by the fungicides iprodione, procymidone and vinclozolin. Pesticide Science, oxford, 10: $389-92,1979$.

GEORGOPOULOS, S.G. \& ZARACOVITIS, C. Tolerance of fungi to organic fungicides. Annual Review of Phytopathology, Palo Al to, 5: $109-30,1967$.

GHINI, R. Caracterização morfológica, serológica e patogênica de espécies de Botrytis que ocorrem na cultura da cebo 1 a (AZlium cepa L.) Piracicaba, 1984. 53p. (Mestrado - Es cola Superior de Agricultura "Luiz de Queiroz"/USP) 
GHINI, R. \& KRUGNER, T.L. Ocorrência de Botrytis cinerea resistente a benomyl em viveiro de Eucalyptus viminalis, em Três Barras - SC. Summa Phytopathologica. Resumos do 100 Congresso Paulista de Fitopatologia, Piracicaba, 1987. Pi racicaba, Grupo Paulista de Fitopatologia, 1987. p.36.

GILLMAN, L. S. \& JAMES, R. L. Fungicidal tolerance of Botrytis, within Colorado greenhouses. Tree Planters Notes, Washingtion, $31(1): 25-8,1980$.

GRINDLE, M. Phenotypic differences between natural and induced variants of Botrytis cinerea. Journal of General Microbiolo9y, London, 111:109-20, 1979 .

GULLINO, M. L. \& GARIBALDI, A. Competition in vitro and in vivo between strains of Botrytis cinerea Pers. sensitive and resistant to dicarboximides. Netherlands Journal of Plant Pathologgy, Wageningen, 87: 243, 1981 .

GULLINO, M.L. \& GARIBALDI, A. Monitoring the spread of dicarboximide and benzimidazole - resistant strains of Botrytis cinerea in italian vineyards. In: INTERNATIONAL WORKSHOP ON EPIDEMIOLOGY OF PLAN DISEASES. 5. Jerusalēm, 1986. Summaries of Contributions . 
HARTILL, W.F.T.; TOMPKINS, G.R.; KLEINSMAN, P.J. Development in New Zealand of resistance to dicarboximide fungicides in Botrytis cinerea, to acylalinines in Phytophthora infestans, and to guazatine in Penicillium italicum. New Zealand Journal of Agricultural Research, Wellington, 26: $261-9,1983$.

HISADA, Y.; TAKAKI, H.; KATO, T.; OZAKI, T.; KAWASE,Y.FitnesS of procymidone - resistant Botrytis cinerea strains developed in vitro. Netherlands Journal of Plant Pathology, Wageningen, 87:243, 1981

IIDA, W. On the tolerance of plant pathogenic fungi and bacteria to fungicides in Japan. Japan Pesticide Information, Tokyo, (23):13-6,1975.

JARVIS, W. R. \& HARGREAVES, A. J. Tolerance to benomy 1 in Botrytis cinerea and Penicillium corymbiferum. Plant Pathology, 0xford 2z:139-41,1973.

JORDAN, V. W. L. \& RICHMOND, D. V. The effects of benomy on sensitive and tolerant isolates of Botrytis cinerea infecting strawberries. Plant Pathology, 0xford, 23:81-3, 1974. 
KAARS SIJPESTEIJN, A. Effects on fungal pathogens. In: MARSH, R.W., ed. Systemic fungicides. 2. ed. London, Butler \& Tanner, 1977. cap. 7, p. 131-59.

KATAN, T. Persistence of dicarboximide-fungicide res is tance in populations of Botrytis cinerea in a warm, dry temperate agroclimate. Phytoparasitica, Dagan, 10 (3):209-11,1982a.

KATAN, T. Resistance to 3,5 - dichlorophenyl - N. cyclic imide ('dicarboximide') fungicides in the grey mould pathogen Botrytis cinerea on protected crops. Plant Pathology, 0xford, 31:133-41,1982b.

KATAN, T.; SHABI, E.; GILPATRICK, J. D. Genetics of resis tance to benomy 1 in Venturia inaequalis isolates from Is rael and New York. Phytopathology, St. Paul, 73 (4):600, - 3, 1983.

KIMATI, H. Fungicidas. In: GALLI, F, coord. Manual de fitopa tologia. 2. ed. São Paulo, Editora Agronōmica Ceres, 1978. v 1, cap. 18, p. 325-73.

KIMATI, H. Resistēncia de fitopatógenos a substāncias quími cas usadas no controle de doenças de plantas. In: CONGRES SO PAULISTA DE FITOPATOLOGIA, 10., Piracicaba,1987. Summa Phytopathologica. Piracicaba, Grupo Paulista de Fitopato logia, $13(1,2): 72-4,1937 a$. 
KIMATI, H. Resistēncia de fungos a fungicidas e a importāncia do monitoramento. Agrotécnica, São Paulo, (1):5-7,1987b.

KIMATI, H.; SOAVE, J.; ESKES, A.B.; KUROZAWA, C.; BRIGNANI NETO, F.; FERNANDES, N. G. Guia de fungicidas agricolas. Piracicaba, Livroceres, 1986. 281 p.

KIRBY, A.H.M. Progress towards systemic fungicides PANS, Hampshire, 18(1):1-33,1972.

LAMBERT, D. H. \& WUEST, P. J. Acid production, a possible basis for benomyl tolerance in Verticizlium malthousei. Phy topathology, St. Paul, 66:1144-47, set. 1976.

LEROUX, P. \& CLERJEAU, M. Res is tance of Botrytis cinerea Pers. and Plasmopara viticola (Berk. \& Curt) Berl. and de Toni to fungicides in irench vineyards. Crop Protection, Guilford $4(2): 137-60,1985$.

LEROUX, P.; FRITZ, R.; GREDT, M. Etudes en laboratoire de souches de Botrytis cinerea Pers, resistantes à la dichlozoline, au dicloran, au quintozene, à $1 \mathrm{a}$ vinchlozoline et au 26019PP (ou glycophene). Phy topathologische Zeitschrift, Berlin, 89: 347-58,1977. 
LITTLEY, E. R . \& RAHE, J.E. Specific tolerance of Sclerotium cepivorum to dicarboximide fungicides. Plant Disease, St. Paul, 68 (5):371-4, mai. 1984.

MARTIN, D. Contribution a l'etude du pouvoir pathogene et de la resistance au benomyl de Venturia inaequalis (CKE.) Wint: competition entre biotypes et heredite des caracteres. Paris, 1982. 115 p. (Doutorado - Centre d'Orsay/Universite de Paris - Sud).

MILLER, M. W. \& FLETCHER, J. T. Benomy 1 , tolerance in Botrytis cinerea isolates from glasshouse crops. Transactions British Mycological Society, London, $62(1): 99-103,1974$.

MILLER, M. W. \& JERVES, T. M. The pers is tance of benomy tolerance in Botrytis cinerea in glasshouse tomato crops. Plant Pathology, 0xford, 28:119-22,1979.

MORGAN, D.J. Numerical taxonomic studies of the genus Botrytis. Transactions Eritish Mycological Society. London, 55 (3): $327-35,1971$.

NACHMIAS, A. \& BARASH, I. Decreased permeability as a mechanism of resistance to methyl benzimidazol-2-yl carbamate (MBC) in Sporobolomyces roseus. Journal of General Microbiology, London, $94: 167-72,1976$. 
NORTHOVER, J. \& MATTEONI, J.A. Res istance of Botrytis cinerea to benomyl and iprodione in vineyards and greenhouses after exposure to fungicides alone or mixed with captan. Plant Disease, St. Paul, 70 (5):398-402,1986.

PANAGIOTAKU, M. G. \& MALATHRAKIS, N.E. Resistance of Botrytis cinerea Pers. to dicarboximide fungicides. Netherlands Journal of Plant Pathology, Wageningen, 87:242,7981.

PAPPAS, A. C. \& FISHER, D. J. A comparison of the mechanisms of action of vinclozolin, procymidone, iprodione and prochloraz against Botrytis cinerea. Pesticide Science, $0 \times$ ford, $10: 239-46,1979$.

PAPPAS, A. C.; COOKE, B. K.; JORDAN, V. W. L. Insensitivity of Botrytis cinerea to iprodione, procymidone and vinclozolin and their uptake by the fungus. Plant Pathology, $0 \times$ ford, $28: 71-6,1979$.

PEARSON, R.C.; ROSENBERGER, D.A.; SMITH, C. A. Benomy 1 - resistant strain of Botrytis cinerea on apples, beans, and grapes. Plant Disease, St Pau1, 64(3):316-8, mar. 1980.

PEPIN, H. S. \& MacPHERSON, E. A. Strains of Botry tis cinerea resistant to benomyl and captan in the field.Plont Disease, St.Paul, 66(5):404-5,1982. 
POLACH, F. J. \& MOLIN,W. T. Benzimidazole - resistant mutant derived from a single ascospore culture of Botryotinia fuckeliana. Phytopathology, St. Paul, 65:902-4, ago. 1975.

POMMER, E. H. \& LORENZ, G. Resistance of Botrytis cinerea Pers. to dicarboximide fungicides - a literature review. Crop Protection, Guildford, I (2):221-30, 1982.

PRESLY, A. H. \& MAUDE, R. B. Control of Botrytis einerea and Botrytis squamosa in overwintered salad onion by fungicide sprays. Annals of Applied Biology, Wellesbourne, 94:197$204,1980 \mathrm{~b}$.

PRESLY, A. H. \& MAUDE, R. B. The effect of seed treatment with benzimidazole - based fungicides on infection of the foliage of overwintered salad onions by Botrytis cinerea. Annals of Applied Biology, Wellesbourne, 94:185-96,1980a.

PRESLY, A. H. \& MAUDE, R. B. Tolerance in Botrytis squamosa to iprodione. Annals of Applied Biology, Wellesbourne, $100: 117-27,1982$.

RUPPEL, E. G. Biology of benomyl - tolerant strain of Cercospora beticola from sugar beet. Phytopathology, St. Paul, 65:785-9, ju1. 1975. 
RUPPEL, E. G.; JENKINS, A. D.; BURTCH, L.M. Persistence of benomy 1 - tolerant strains of Cercosporabeticola in the absence of benomy 1. Phytopathology, St. Paur, 70(1): 25 6,1980 .

SCHREIBER, L. R. \& TOWNSEND, A. M. Naturaliy occurring tolerance in isolates of Ceratocystis ulmi to methyl 2 benzimidazolecarbamate hydrochloride. Phy topathology, St. Paul, 66:225-7, fev. 1976 .

SCHROEDER, W. T. \& PROVVIDENTI, R. Res is tance to benomy 1 in powdery mildew of cucurbits. Plant Disease Reporter, Washington, $53(4): 27 i-5$, abr. 1969.

SCHUEPP, H. \& KUNG, M. Stability of tolerance to $M B C$ in populations of Botrytis cinerea in vineyards of northern and eastern Switzerland. Canadian Journal of Plant Pathology, Guelph, 3:180-1,1981.

SOULIER, G. Etude experimentale de la resistance des Venturia aux benzimidazoles. Lyon, 1984. 110 p. (Doutorado - U.E.R. Faculte de Pharmacie Universite de Lyon).

STAUB, T, \& SOZZI, D. Fungicide resistance: a continuing challenge. Plant Disease, St. Paul, 68(12):1026-31, dez. 1984 . 
TOLEvo, A. C. D. de. Resistēncia a fungicidas. O Biológico, São Paulo, 40: 163-70, 1974 .

TRIPATHI, R. K. \& SCHLOSSER, E. The mechanism of resistance of Botrytis cinerea to methyl benzimidazol - 2 - yl carbamate (MBC). Journal of Plant Disease and Protection, Stuttgart, 89 (3):151-6,1982.

TUYL, J. M. var. Genetics of fungal resistance to systemic fungicides. Mededelingen Landborwhogeschool, Wageningen, 77-2, $1977.236 p$.

TUYL, J. M. yan; DAVIDSE, L. C.; DEKKER, J. Lack of cross resistance to benomy 1 and thiabendazole in some strains, of Aspergizzus nidulans. Netherlands Journal of Plant Pathology, Wageningen, 80:165-8, 1974.

WATSON, A. G. \& KOONS, C. E. Increased tolerance to benomy 1 in greenhouse population of Botrytis cinerea. Phytopathology St. Pau1, 63:1218-9,1973.

WEBSTER, R. K.; OGAWA, J. M.; BOSE, E. Tolerance of Botrytis cinerea to 2,6 - dichloro - 4 - nitroaniline.Phytopathology, St. Paul;60;1489-7492, out. 1970 .

WUEST, P. J.; COLE JR.,.H.; SANDERS, P. L. Tolerance of Verticillium mal thousei to benomyl. Phy topathology, St. Paui, 64:331-4, mar. 1974 . 